\title{
PHILEMON, KA, AND CREATIVE FANTASY: THE FORMATION OF THE RECONCILING SYMBOL IN JUNG'S VISUAL WORK, 1919-1923
}

DIANE FINIELLO ZERVAS

PHANÊS • VOLUME 2 • 2019 • PP. 59-103

https://doi.org/10.32724/phanes.2019.Zervas 


\begin{abstract}
Thanks to the publication of The Red Book (2009) and The Art of C.G. Jung (2019), we now have a substantial corpus of the visual works that Jung created between 1913 and 1923, a period when he was deeply engaged with Liber Novus, its transcription and elaboration into The Red Book, whilst at the same time formulating the core concepts of analytical psychology. This article identifies several previously unrecognised representations of two of Jung's most important personifications, the 'dominant fathers' Philemon and Ka. I then trace their roles in some of Jung's visual works that include the image of the cross-quartered circle and sphere, his prime example of the reconciling symbol of the creation of the new god, and of individuation. After examining two paintings in detail, Amor Triumphat (1920-21) and Cat. 66 in The Art of C.G. Jung (c. 1921-23), I conclude with Jung's designs for Emma Jung's memorial at Bollingen (1956), and his family tomb at Küsnacht (1957).
\end{abstract}

\title{
KEY WORDS
}

Jung's visual work, Liber Novus, The Red Book, Philemon, Ka, the reconciling symbol, Amor Triumphat, mandalas. 
'The real history of the world seems to be the progressive incarnation of the deity.'

(Jung 1976:436)

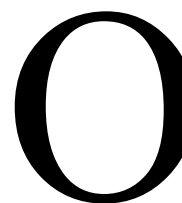

ver the eighty years since Jung first anonymously published three of his mandala paintings in his commentary to The Secret of the Golden Flower (1929/1931:Plates 3, 6, 10; RB:159, 105, 163), a few more paintings from The Red Book and other visual works that he did over his lifetime gradually came to light. Viewed in isolation, they were often interpreted in ways that foregrounded their 'universal meaning': serving to illustrate Jungian concepts (typology, mandala, shadow, anima, wise old man etc.) as reified within the thematic format of the Collected Works, whilst remaining uprooted from their historical position within the chronology of Jung's developing conceptual framework.

With the publication of The Red Book in 2009, however, students of Jung are finally able to examine contextually the visual images he created to illustrate the text of Liber Novus (1913-1917), and those that are independent of its narrative, relating to Jung's further visionary experiences and experiments between 1917-1929/30. Now augmented by the works presented in The Art of C.G. Jung (2019), our knowledge of Jung's visual imagery has increased extensively (save for that inside Bollingen).

This wealth of new material has enabled me to examine some of Jung's paintings and sculptures within their proper chronological and historical context for the first time, and to highlight their unique role within 
Jung's ongoing conceptual explorations, thus confirming his statement in 'The Way of What is To Come', the introductory chapter to Liber Novus: 'My speech is imperfect. Not because I want to shine with words, but out of the impossibility of finding those words, I speak in images' (RB RE:123).

Not surprisingly, Jung's newly enlarged corpus of visual works contains some surprises. In particular, I have been able to identify some previously unrecognised - and therefore unexploredpersonifications of characters who first appeared in his Black Books and Liber Novus between 1913 and 1930, as well as paintings that explicate-and in some cases anticipate-concepts that Jung was transposing from image to word in his concurrent articles and books.

This article will review the emergence of the 'fathers' Elijah to Ka in Liber Novus and the published sections of the Black Books. Working from these sources and other related material, it is possible to identify five previously unrecognised images of Philemon and Ka. Their role is then examined in paintings that include the image of the crossquartered circle and sphere, Jung's prime example of the reconciling symbol, through which his new god, Phanês, appears, and to which he returns throughout his life. Amor Triumphat (1920-1921), one of Jung's most moving paintings in The Red Book, epitomises the ability of the reconciling symbol to encompass complex hermeneutics, as do the figures in another of Jung's paintings (Art:145, Cat. 66). After a brief discussion of the first round tower at Bollingen (1923), the article concludes with the two late works where Jung eternalised the cross-quartered circle in stone: Emma Jung's memorial (1956), and the Jung family tombstone (1961).

\section{THE ANCIENT FATHERS: FROM LIBER NOVUS TO THE BLACK BOOKS}

During the first few months of Jung's confrontation with the unconscious, between November 1913 and April 1914, he encountered three personalities who played an important part in Liber Novus, acting as teachers and guides during his initiation process and search for a new god-image. These were the prophet Elijah, the Babylonian Bull God Izdubar, and Philemon, magician and father of the prophets, who had given Jung the Seven Sermons to the Dead, and whom Jung came to recognise as his guru (Jung/Jaffé:174-177). ${ }^{1}$

\footnotetext{
${ }^{1}$ Elijah first appears with his blind daughter Salome and the serpent in the historiated initial at the beginning 'Mysterium. Encounter', made during the autumn of 1915 $(\mathrm{RB}: \mathrm{HI} \mathrm{v}(\mathrm{v}))$. Izdubar is depicted twice in 'First Day': as the imposing giant that
} 
Three years later, in 1917, another significant trio emerged in the fantasies that Jung recorded in his Black Books: Atmavictu, Ha and Ka. ${ }^{2}$ Atmavictu arrived first. On 25 April 1917, the serpent, Atmavictu's companion over millennia, described his previous existences to Jung. He was first an old man, then an otter, newt, earth serpent, man, and the serpent-Atmavictu. He also transformed into Philemon (RB RE:367 n. 222). In another encounter on 20 May 1917, Philemon clarified that he had been Atmavictu; then, by error, he had become Izdubar, was paralysed and turned into a dragon's serpent by man. After the serpent was consumed by fire, Philemon had come into being. Thus he was reinterpreting the events earlier narrated and illustrated by Jung in the Izdubar episode of Liber Novus ([1913/14], LN RE:372 nn. 231-232).

$\mathrm{Ha}$ - a 'black magician' and 'father of Philemon' - materialised a few months later, on 7 October 1917. He explained the secret meaning of the runes that Jung had drawn in three mandala sketches whilst still on military duty at Chateau d'Oex the previous month, and would subsequently paint in The Red Book (LN RE:325-327 nn. 155-157). ${ }^{3}$ Ha was soon followed by $\mathrm{Ka}$, who appeared on 22 October 1917. With eyes of pure gold, and a body of black iron, he was Ha's soul. He had imparted the knowledge of the runes and the lower wisdom to Ha. Ka held a secret that Jung and his soul needed; this was love, the essence of all magic (RB RE:373 n.232). In a Black Book entry on 20 November 1917, Ka then called Philemon his shadow and herald. He states that he is eternal, and remains, whereas Philemon is fleeting and passes on. Ka returned on 10 February 1918 to inform Jung's 'I' and soul that he had built a temple as a prison and grave for the gods (ibid).

In 1919, a year of intense work on Psychological Types, accompanied by professional activities, Jung began to craft visual images of some of these personages in The Red Book and as separate creations. From Memories, Dreams, Reflections, we know that he made a painting of Philemon as a winged being with bull's horns (Jung/Jaffé 1963:176). Although now missing, Jung's sketch for it has survived, drawn on or after 3 January 1919,

Jung completed on Christmas Day 1915, and then as a prone figure in late 1915-early 1916, before being transformed into an egg and hatching into a new god image in 'The Opening of the Egg', begun on 4 February 1917 (RB:36, 44, 64). Philemon plays an important part in 'The Magician' and throughout Scrutinies. His images are discussed below.

${ }^{2}$ See the Appendix $A$ for the chronology of texts and art works discussed in this article.

3 The mandala sketches are reproduced in Art:197, Cat. 91 sketch 15 (1 September 1917), 203, Cat.23 sketch 23 (10 September 1917), 204, Cat.100, sketch 24 (11 September 1917). They were used for RB 89, 93-94, done after 15 October 1917 (Zervas 2019:196-209). 
providing a terminus post quem for the painting (Art:146-147, Cats. 64-65). He made two images of Atmavictu as a multi-legged dragon in The Red Book, completed sometime between April and November 1919 (RB:117, 119). ${ }^{4}$ They were done around the same time as his two wooden statuettes of Atmavictu, portrayed as an old, bearded six-armed Kabir, carved when Jung was in England during that summer, and the stone copy he subsequently had made for his garden at Küsnacht (Art:152-153, Cats. 67-69).

On 4 December 1919, Izdubar, Philemon, and Ka are described in the enigmatic inscription Jung attached to his Red Book Atmavictu as a petrified head:

This is Atmavictu, the old one, after he has withdrawn from the creation. He has returned to endless history, where he took his beginning. Once more he became stony residue, having completed his creation. In the form of Izdubar he has outgrown and delivered $\Theta \mathrm{I} \Lambda \mathrm{HM} \Omega \mathrm{N}$ and $\mathrm{Ka}$ from him. $\Theta \mathrm{I} \Lambda \mathrm{HM} \Omega \mathrm{N}$ gave the stone, $\mathrm{Ka}$ the $\odot$ [sun] (RB RE:372 n. 231). ${ }^{5}$

Some five years later, Jung painted the Red Book Philemon, 'Father of the Prophet', together with the snake, his earlier manifestation (late 1924/25, RB:154). ${ }^{6}$

There seem to be no visual representations of $\mathrm{Ha}$, and $\mathrm{Ka}$ has previously not been recognised in Jung's Red Book paintings or other extant images. However, as the above descriptions and two other written accounts confirm, Jung depicted Ka at least five times during 1919 and 1920 four together with Philemon-while he was exploring the relationships between Philemon, Atmavictu, $\mathrm{Ha}$, and $\mathrm{Ka}$ in his fantasies. Moreover, the ways in which Jung paired Ka with Philemon in four of these works highlight his efforts during this period to create a pictorial synthesis of his ideas about archetypal images and their representation in matter, and the reconciling symbol of the individuation process, which constellates the

\footnotetext{
${ }^{4}$ While working on The Red Book, Jung started to keep the right-hand pages free for his paintings, thus they were often completed before the calligraphic text he continued to transcribe on the left-hand pages. The two images of Atmavictu on RB 117, 119 were done between 22 March 1919, the date in the margin of RB 110, and November 1919, the date of RB 121 .

5 The inscription is for RB 122, the reverse of RB 121, Lapis Philosophorum, Jung's painting of the Philosopher's Stone.

${ }^{6}$ The large unpublished mural painting of Philemon in one of the bedrooms of Jung's first tower at Bollingen is presumably slightly later, given the chronology of its construction.
} 
new god and the Self. They are thus crucial visual counterparts to Jung's written concepts in Psychological Types, or as more properly described in its English subtitle, The Psychology of Individuation (Jung 1923).

\section{FORMING THOUGHTS IN MATTER: PHILEMON, KA, THE RECONCILING SYMBOL, AND PHANÊS}

Before the publication of The Red Book, the main source of information about $\mathrm{Ka}$ was Jung's account of Philemon and $\mathrm{Ka}$ as edited by Anelia Jaffé in Memories, Dreams, Reflections, which also includes a description of painting he made of them:

[. . .] Philemon became relativized by the emergence of yet another figure, whom I called Ka. In ancient Egypt the 'king's ka" was his earthly form, the embodied soul (Gestaltseele). In my fantasy the ka-soul came from below, out of the earth as if out of a deep shaft. I did a painting of him, showing him in his earth-bound form, as a herm with a base of stone and upper part of bronze. High up in the painting appears a kingfisher's wing, and between it and the head of Ka floats a round, glowing nebula of stars. Ka's expression has something demonic about it —one might also say, Mephistophelian. In one hand he holds something like a coloured pagoda, or a reliquary, and in the other a stylus with which he is working on the reliquary. $\mathrm{He}$ is saying, "I am he who buries the gods in gold and gems."

Philemon had a lame foot, but was a winged spirit, whereas $\mathrm{Ka}$ represented a kind of earth demon or metal demon. Philemon was the spiritual aspect, or "meaning" ("der Sinn”). Ka, on the other hand, was a spirit of nature (ein Naturgeist) like the Anthroparion of Greek alchemywith which I was still unfamiliar. Ka was he who made everything real, but who also obscured the halcyon spirit (den Eisvogelgeist), Meaning, or replaced it by beauty, the "eternal reflection." (Jung/Jaffé 1963:177-178, 1971:206).

Jaffé adapted this from Jung's passage on active imagination and The Red Book in the interviews - Protocols - recorded for Memories, Dreams, Reflections (Protocols [June 19, 1957]:23-25). ${ }^{7}$ They took place when

${ }^{7}$ See Shamdasani (1995:117-126) for the convoluted history of the publication of Memories, Dreams, Reflections. 
Jung was still considering what to do with Liber Novus, hence he included frequent references to its text and characters (Shamdasani in RB RE:91-93). In the Protocols, Jung called Ka a 'stone soul' (Steinseele). Describing his painting, Jung stated that $\mathrm{Ka}$ is made of 'stone or metal, like a metal herm'. Philemon hovered above in the light, his wing visible, but Jung did not mention a 'round, glowing nebula of stars' between the two figures. Ka holds a 'surrealistically decorated (geschmücktes) object' in his hand, not a 'pagoda' or 'reliquary' .

Jaffé deleted the penultimate sentence in Jung's original explanation of Ka, a quote from Goethe's Faust, Part II. Jung had said: 'He [Ka] who replaces meaning with beauty, with the "eternal reflection". "That life is ours by colourful refraction" ("Am farbigen Abglanz haben wir das Leben': Goethe, Faust II, line 4727). ${ }^{8}$ She also altered Jung's last sentence about the consequences of Ka's replacing meaning with beauty. He had stated: 'But meaning, the master of the garden, is lost'; in Memories, Dreams, Reflections, Jaffé replaced 'der Herr des Gartens' with 'the halcyon spirit' ('den Eisvogelgeist'-kingfisher spirit-in the German edition), probably because of the decision to exclude Liber Novus references, which would have linked 'der Herr des Gartens' with Philemon in 'The Magician' and the final section of 'Scrutinies' (RB RE:412, 552). In a later section of Protocols, Jung relates Philemon and $\mathrm{Ka}$ to the problem of the reconciliation of the opposites (Protocols:212). ${ }^{9}$

Jung's late reflections on $\mathrm{Ka}$ and Philemon intimated that their functions needed to be balanced. This conviction had taken root during the years of Liber Novus, and informs the new, moral aesthetic he presented in Psychological Types, in which idea (spiritual) and real (material), ugly and beautiful, good and evil, need to be included as part of the living psychological process in man's psyche that that gathers up the opposites-esse in anima (1921, CW 6:\$77). ${ }^{10}$ Jung's account of $\mathrm{Ka}$ in the Protocols and Memories, Dreams, Reflections is clearly related to his Black Book entries of 1917-1918. Whilst the painting he mentioned is lost, Philemon's position and surroundings

${ }^{8}$ Paul Bishop intuitively surmised a connection with Goethe's line when discussing Jung's phrase 'ewigen Abglanz' in this passage of Memories, Dreams, Reflections (Bishop, 2009:33, 44).

${ }^{9}$ Quoted below in 'We Fear And We Hope': The Grail And The Redemptive Feminine Vessel.

${ }^{10}$ Jung developed his argument for a new aesthetics in Chapter II, 'Schiller's Ideas Upon the Type Problem' in Psychological Types (1923:109-110, 160; CW 6:§§129, 206), a subject he first explored in two lectures for the Zurich Analytical Club in April 1918 (oral communication, Sonu Shamdasani). 


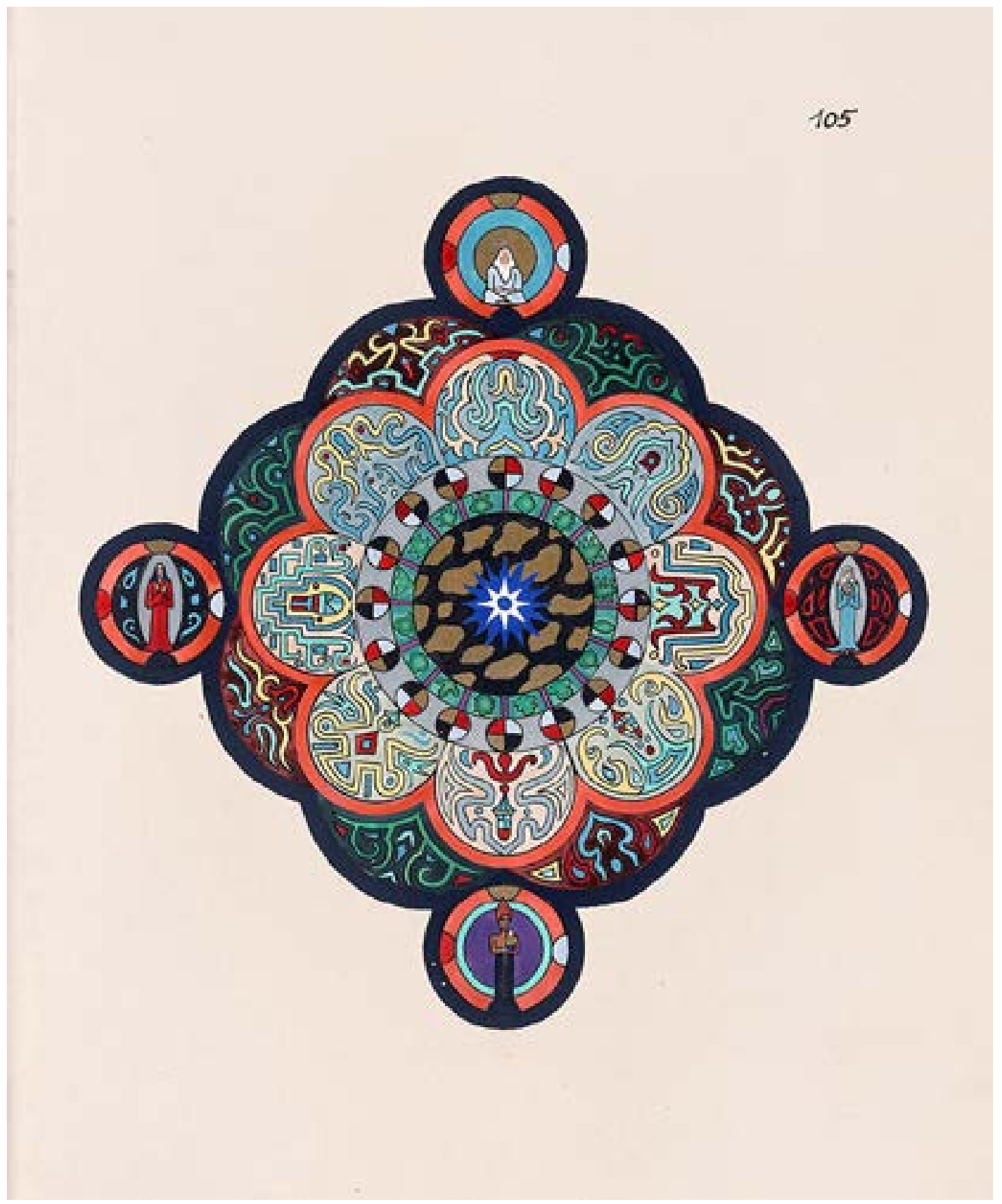

Fig. 1. Mandala, RB 105, 27 January-21 March 1919. (C) used by permission of the Foundation of the Works of C.G. Jung, Zurich. Used with permission of the publisher, W.W. Norton \& Company, Inc. All rights reserved. 
are similar to the above-mentioned sketch and painting that Jung made in 1919, suggesting that he may have reused parts of it for the lost work.

Given the above descriptions of $\mathrm{Ka}$, it is clear that Jung painted him together with Philemon in Red Book mandala 105, which was completed between 27 January and 21 March 1919, shortly after the Philemon sketch (Fig. 1). Philemon, representing 'meaning', the spiritual aspect, sits in a contemplative position in the upper roundel. ${ }^{11}$ The mandala's inner circle contains a small blue sphere centred within two concentric stars, an eight-rayed white one and sixteen-rayed blue one, and set against a blue and gold cloud-like nebula. Ka, the embodying 'stonesoul', stands in the bottom roundel. The mandala's vertical composition therefore reflects the configuration of the lost painting of Philemon and Ka described in Memories, Dreams, Reflections. Ka's lower body is encased in a black herm-like column. He has a bronze torso, flaming red hair, and holds a temple decorated with tesserae in the primary colours of blue, yellow and red. He is a daimonic being who has emerged from the black earth, formed from matter's hardest elements, stone and metal. ${ }^{12}$

Similarly, $\mathrm{Ka}$ is the subject of a wooden statuette that Jung carved, probably close to the execution of Red Book 105 in 1919 (Fig. 2) (Art:119-121, Cat. 49). ${ }^{13}$ This was a period when, as his English colleague Maurice Nicoll later reminded him, Jung was experimenting with 'the possibilities of psycho-material transformation-i.e. if a man puts his psychic genius into a bit of wood, the wood stands up to him and in fact it is an example of psycho-transformation' (Pogson

\footnotetext{
${ }^{11}$ Philemon was not winged or horned when Jung first encountered him in January 1914 (RB RE:395-397).

${ }^{12}$ When Jung anonymously published RB mandala 105 in his commentary to The Secret of the Golden Flower, he described the centre as 'the white light, shining in the firmament', and the roundel figures at the cardinal points as 'masculine and feminine souls, both again divided into light and dark' (Jung 1929, CW 13:ill. A6). In his unpublished 1937 Berlin seminar, the centre is 'the blue heaven containing golden clouds', the upper figure 'an older man in a contemplative position', and the lower one 'Loki with red flaming hair, who holds a temple in his hand' (1937:37, and Abbildung 29; the seminar is erroneously dated 1930 in 1934/50, CW 9, 1:355 n. 1). When Jung revised it as 'Concerning Mandala Symbolism' in 1950, he commented: 'In the centre is a star. The blue sky contains golden clouds'. At the top is 'an old man in the attitude of contemplation', who corresponds to the 'archetype of meaning, or of the spirit [...], the Wise Old Man'. At the bottom is 'Loki or Hephaestus with red, flaming hair' holding a temple, $[\ldots]$ the dark chthonic figure corresponding to the magical (and sometimes destructive) Luciferian element' (1950, CW 9, 1:§682). Thus Ka remained an esoteric figure known only to a select few of Jung's inner circle until the publication of Memories, Dreams, Reflections.

13 There, however, identified as Loki, and dated ca. 1920.
} 


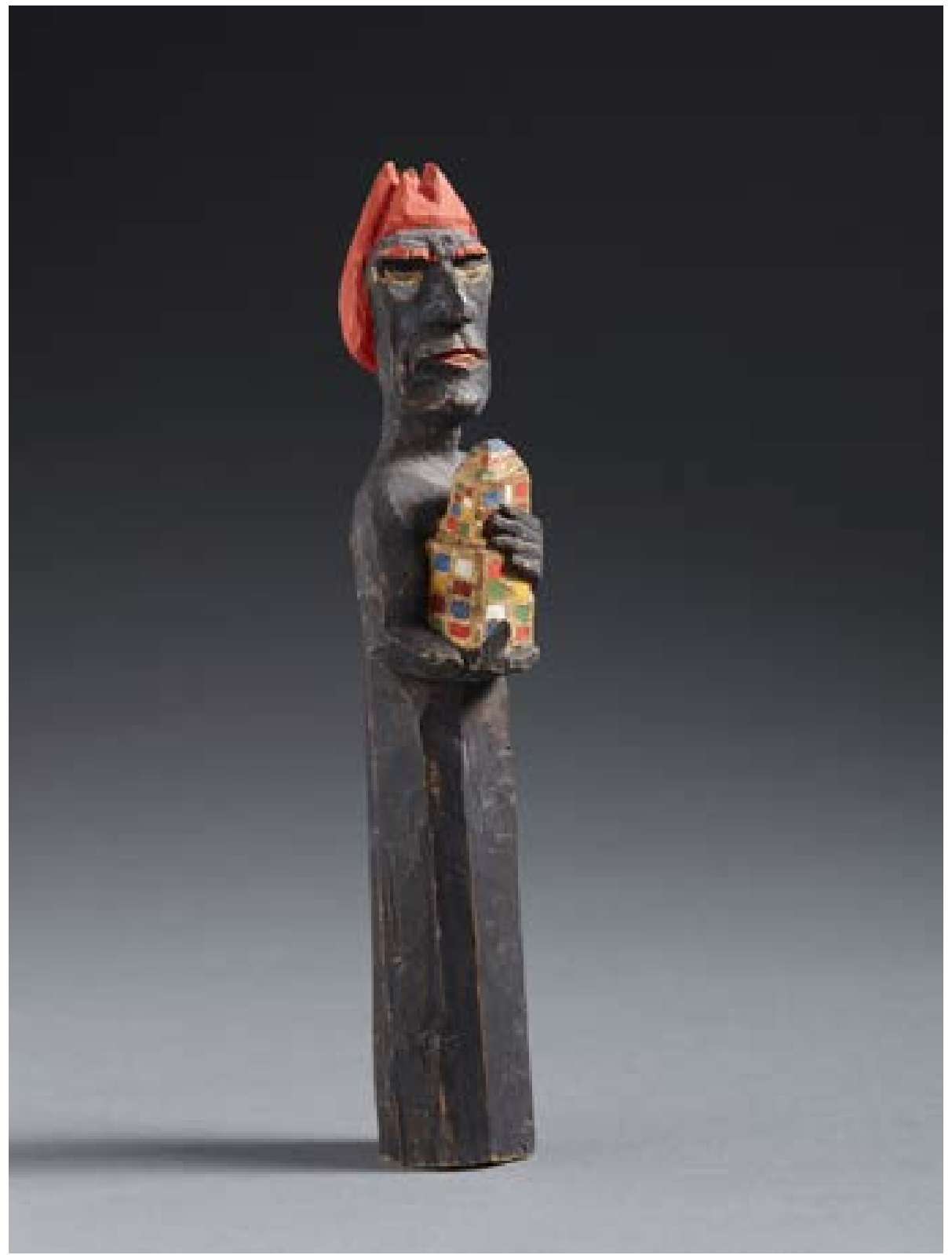

Fig. 2. Ka. Wooden statuette, ca. 1919. Art, Cat. 49. Jung Family Archive (C) The Foundation of the Works of C.G. Jung, Zurich. 
1961:65). Ka's entire herm-based body is painted black, his face has a devilish expression, half-moon golden eyes, red eyebrows, flaming red hair, and he cradles a gold, gem-studded temple in his hands.

We now know that Jung had portrayed $\mathrm{Ka}$ and Philemon in another painting completed sometime before 15 October 1920, when he discussed it with Constance Long (see Appendix B). From her summary, we learn that Jung placed them on the two sides of the work; they are the 'personifications of dominants': the 'fathers'. Ka (Dionysian), is the 'creative' father. He gives substance and is called 'the one who buries the gods in gold and marble'. Ka has a 'tendency to imprison the gods in matter', 'so they are in danger of losing their spiritual meaning and becoming buried in stone'. Thus the temple may be the 'grave of God, as the church is the grave of Christ'; 'the more the church develops, the more Christ dies'. Ka must be prevented from producing too much, because man must not depend on substantiation, although if too little substance is produced, 'the creature floats'. 'Ka is sensation'. Philemon (Apollonian) is the other 'father', the one who 'gives form and law, the formative instinct'. $\mathrm{He}$ 'gives formulation to the things within the elements of the collective unconscious, the idea ('perhaps of a god)', which however remains 'floating, distant and indistinct because all the things he invents are winged'. ${ }^{14}$

Jung told Long that the transcendent function is the whole - not the picture or his rationalisation of it - 'but the new and vivifying creative spirit that is the result of the intercourse between the conscious intelligence and the creative side'. 'Philemon is intuition', 'too supra-human', Zarathustra, 'extravagantly superior in what he says', and 'cold'. Ka and Philemon 'are bigger than the man, they are supra-human. (Disintegrated into them one is in the collective unconscious)' (RB RE:373-4 and n. 232).

In fact, the description of this work corresponds exactly to a small painting in the Jung Family Archive, ca. 1919 (Fig. 3) (Art:126, Cat. 54). On the left, a monumental $\mathrm{Ka}$ with coned-shaped hair sits in a statuesque, Egyptian-type profile, formed by tessellated elements from the unconcious in tones of fiery red and gold. With his arm extended, Ka presents his gem-encrusted, golden temple, similar to those in Red Book mandala 105 and the wooden statuette of Ka. Bearded Philemon sits on the right side, with a small sphere floating above his head (symbolising the floating 'idea', 'perhaps of a god'); both are composed of greentoned, tessellated elements. ${ }^{15} \mathrm{He}$ presents his book, '7 SERMONES AD

${ }^{14}$ This remark may refer back to Philemon's comment 'my form is appearance' in the Black Book fantasy of 20 May 1917 (RB RE:373 n. 232).

${ }^{15}$ This combination of Philemon and a floating sphere may relate to the mysterious 


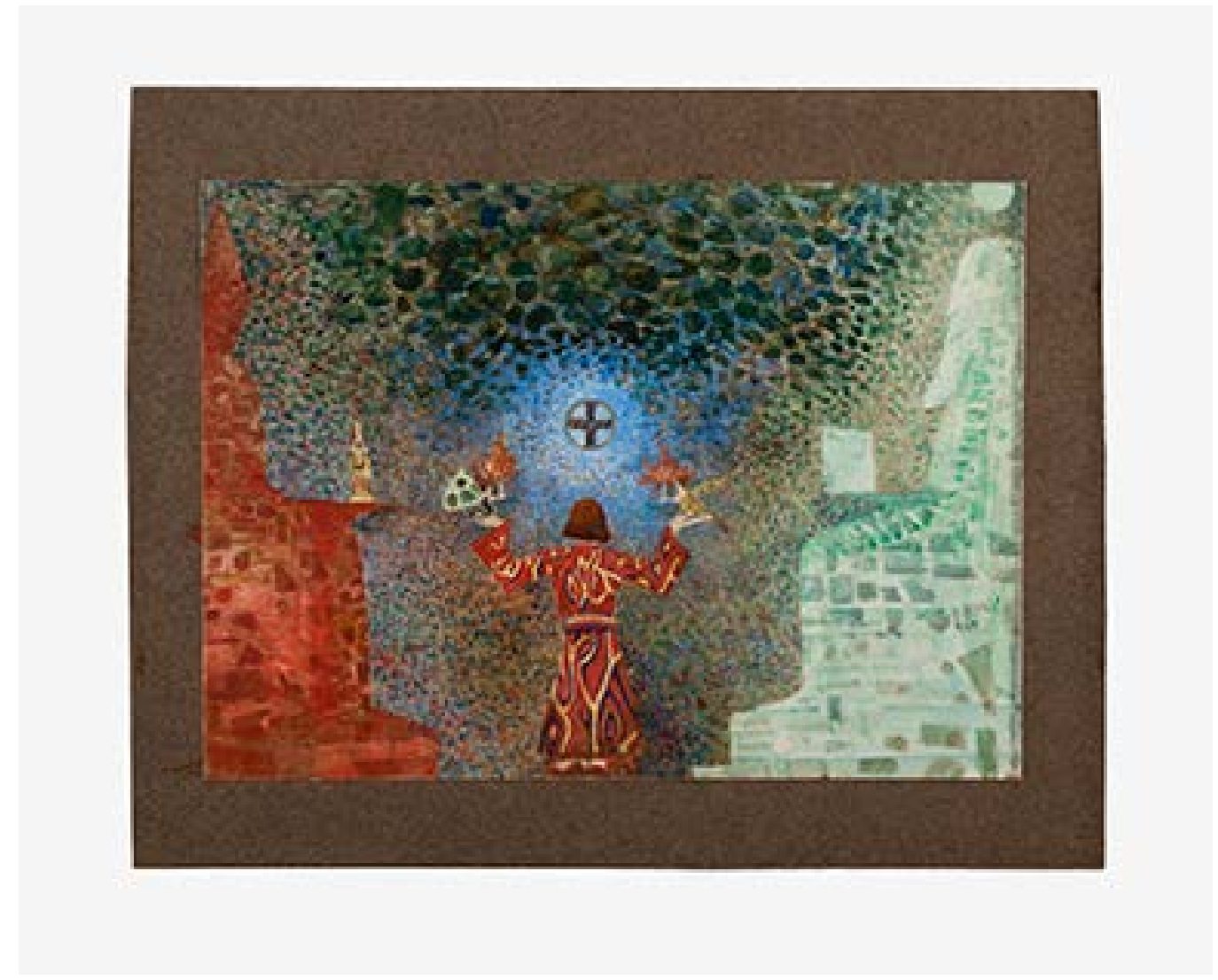

Fig. 3. Ka, Philemon, Priest holding the Winged Snake-Woman and Winged Bird-Woman, and the Reconciling Symbol, ca. 1919. Art, Cat. 54. Jung Family Archive (C) The Foundation of the Works of C.G. Jung, Zurich. 


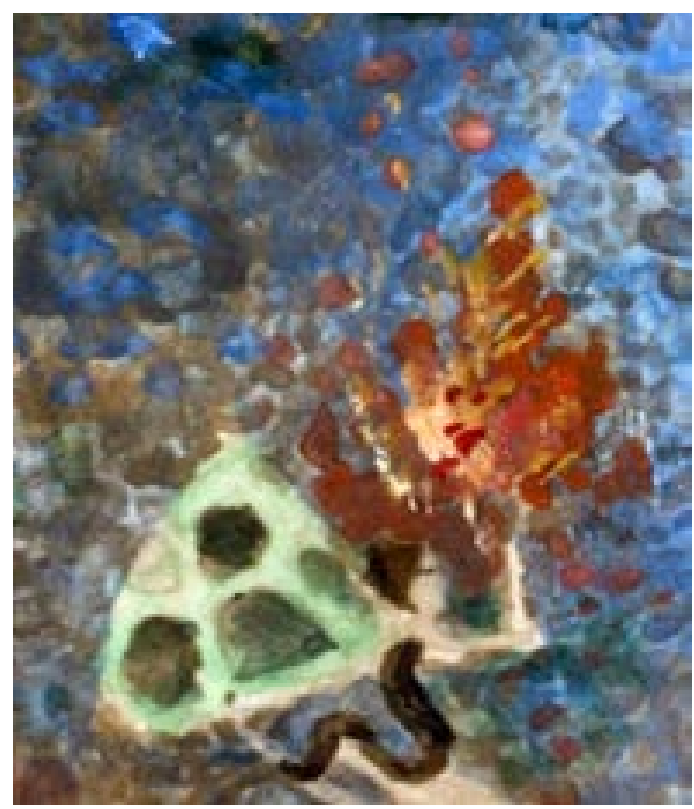

Fig. 3a. Detail, Winged Snake-Woman, ca. 1919. Art, Cat. 54. Jung Family Archive (C) The Foundation of the Works of C.G. Jung, Zurich.

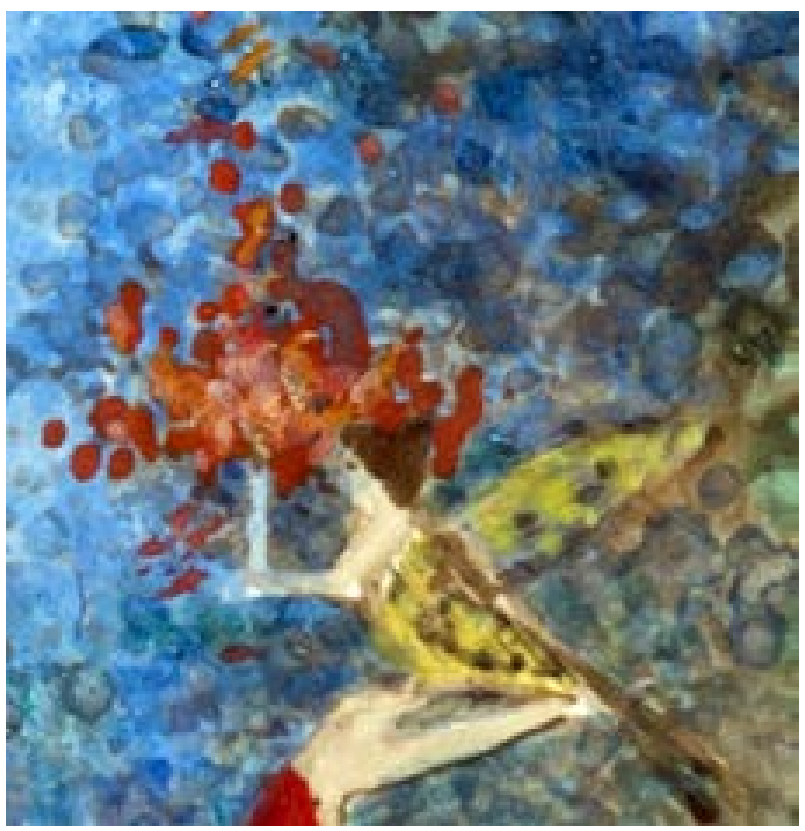

Fig. 3b. Detail, Winged Bird-Woman, ca. 1919. Art, Cat. 54. Jung Family Archive (C) The Foundation of the Works of C.G. Jung, Zurich. 
MORTUOS' (The Seven Sermons to the Dead) a cosmology formulated in words. Between them, a priest in a red robe decorated with black and yellow motifs - 'The Man' in Long's summary — kneels, his back toward us, with raised arms. He represents the inferior function. 'The colours are barbarous, and represent the four functions'. Jung compares the rite the priest performs to the 'divine service for the "dead" (sermon ad mortuos)' in the 'Night of the Flaming Censer' (in John Hubbard's The Authentic Dreams of Peter Blobbs, 1916). In the painting there is no censer; 'it is expressed in words; invocation, adorations of god, maybe speechless ... here is a word (sermo) or prayer', relating it to the book of Sermones that Philemon holds. In each hand he holds a small object bearing a flaming torch. The left one, on Ka's side, is a black snake-woman with dark hair and green tessellated 'wings', a symbol of Ka's substance-giving properties. The right one, on Philemon's side, is a yellow bird-woman with light hair, a symbol of Philemon's formative, winged inventiveness. As Jung discussed with Long, the snake and bird 'is the same anima split into halves'. She 'takes on the quality of the things with which she deals - with those "below" the snake or beauty, creature, and those "above" the bird or winged creature'. They are 'feeling and thinking (as the hands of man), the figures [of Philemon and Ka] are intuition and sensation. When you get in touch with the unconscious they are like great gods'. They are also the chthonic snake and heavenly bird aspects of the soul/anima as narrated in Liber Novus and Black Book 5 (RB RE:389 n. 252, 577), depicted by Jung in The Red Book (RB:HI ii (r) 1 and 2), and his 1916 sketch and painting of the Systema Mundi Totius (RB:364; Art:179), and they are related to the chthonic and spiritual aspects of the feminine in Red Book mandala 105. ${ }^{16}$

By holding the tension between these opposites with religious devotion, the priest has become a creative vessel for the birth of the mysterious symbol above him, in the space between Ka and Philemon. ${ }^{17}$ The heat from their torches has constellated a blue-toned sphere from the surrounding, multicoloured elements. A cross-quartered circle appears to surround the sphere, decorated in diagonal bands of black, red, and blue. Jung explained to Long that this circle has 'four colours twisted around it,' which are 'snake ornaments' that would 'become snakes if the personality

tessellated head with a sphere above and runes below in Red Book 133, completed in the autumn of 1922 .

${ }^{16}$ Jung later equated the snake-woman with the anima in the Zarathustra seminars (Jung 1989, 1:748-751), see Domenici (2018:5-6).

${ }^{17}$ The theme of man as a vessel for the gods is developed in Liber Novus, and discussed at length in Psychological Types (1921, CW 6:especially $§ \S 393-406)$. See below, 'We Fear And We Hope': The Grail And The Redemptive Feminine Vessel. 
should disintegrate'. The four colours are the four functions. Each function has two sides: subjective and objective, external and internal, introversion and extraversion, which are 'constituents of individuality.... The individual monad is a part of the great world of eternity'. Within this circle is an invisible child, symbolising 'onward formulation', bound by the centre of the circle through which, 'via an invisible point [one enters] an enormous space in which the child appears as a constellation in the great distance, i.e. in the future'. 'The child is future', but appears in the individual like a Kabir-man. Jung has created a visual image of creative fantasy, the activity that enables the transcendent function-'a common function of real and imaginary factors' - to produce a living, reconciling symbol from the opposites of substantiation (Ka-sensation) and formulation (Philemon-intuition). ${ }^{18}$

Similar figures of $\mathrm{Ka}$ and Philemon appear in another of Jung's paintings ca. 1919, which he subsequently gave to Helton Goodwin Baynes (Fig. 4) (Art:125, 130, Cat. 53). Their profiles materialise almost imperceivably from a background of large, irregular tesserae in subdued tones of blue and brown, although Ka's red hairdo is clearly visible, composed of five flame-shaped segments. Ka's temple and Philemon's book almost touch the tips of the blood-filled, crescent-shaped gold bowl lifted up by the priest standing between them. ${ }^{19}$ The bird- and snakewomen symbols in Cat. 54 are here replaced by two kneeling women in profile, dressed in robes of different contrasting colours, their hands raised in prayer. As in Cat. 54, a cross-quartered circle surrounds the globe of blue light that floats above the creative feminine vessel, emerging from the negative, scull-like space between the outlined figures of Ka and Philemon.

However, the Baynes painting also includes another figure: Phanês, the Divine Child and Jung's new god. Jung had earlier made two nearly identical paintings of him, now in the Jung family archive (ca. 1917: Art:130, Cats. 50, 51). ${ }^{20}$ Two years later, he completed a similar image of

\footnotetext{
${ }^{18}$ In 'The Problem of Types in History' in Psychological Types, Jung stated that fantasy 'is intuitive just as much as sensational', it is the 'creative activity whence issue the solutions to all answerable questions', the 'mother of all possibilities' (1923:69; slightly differently worded in $1921, \mathrm{CW} 6: \$ 78)$. Jung treated this theme more extensively in 'Schiller and the Type-Problem' and in 'Definitions: Symbol', where sensuality and spirituality are discussed as a pair of opposite functions to be reconciled (ibid: $\$ \$ 184$ $185,174,195,200-206,814-829)$. Jung told Long that by analysing the images of the unconscious, he gave 'a new face to the old beliefs. This gift is the transcendent function' (Appendix B).

${ }^{19}$ The symbolism of the crescent and its feminine-vessel aspects were discussed extensively by Jung and Harding in the 1928-1930 Dream Analysis seminars (Jung 1984:367-389).

${ }^{20}$ In both examples, Phanês emerges from a background of blue or blue green elemental
} 


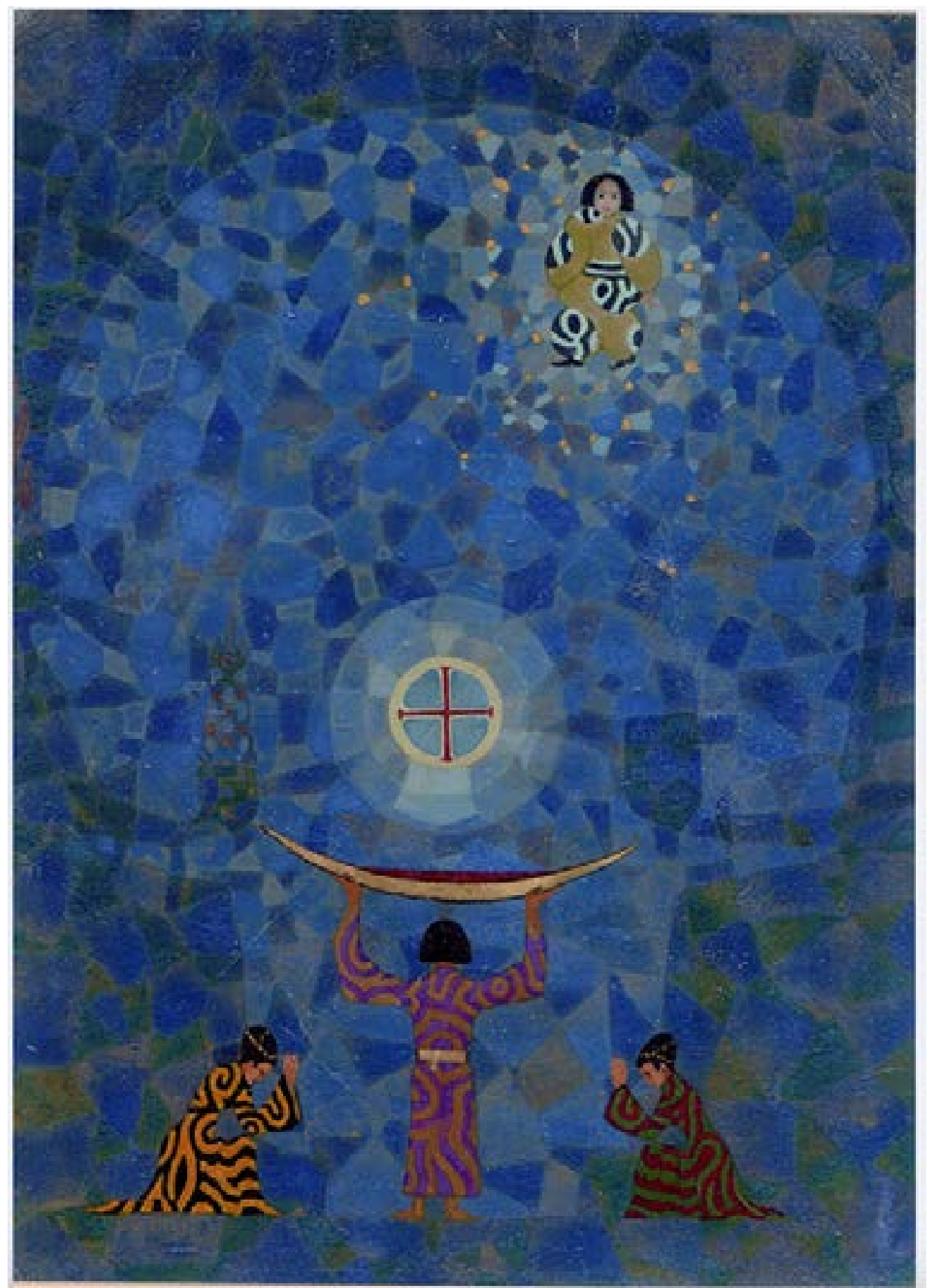

Fig. 4. Ka, Philemon, Phanês, Priest with Crescent, and the Reconciling Symbol, ca. 1919. Art, Cat. 53. Private collection (C) The Foundation of the Works of C.G. Jung, Zurich. 
Phanês in The Red Book, noting:

This is the image of the divine child. It means the completion of a long path. Just as the image was finished in April 1919, and work on the next image had already begun, the one who brought the $\odot$ [sun] came, as $\Phi \mathrm{I} \Lambda \mathrm{HM} \Omega \mathrm{N}$ had predicted to me. I called him ФANH $\Sigma$, because he is the newly appearing God (RB:113). ${ }^{21}$

The figural composition and positioning of Phanês are close in all three paintings. In the Baynes version, however, Jung placed Phanês on the right, in the space above Philemon's Sermon[es] ad Mortuo[s], a visual reminder that, as Philemon had predicted, he would become Phanês (RB RE:358 n. 211). The black-and-white decoration of Phanês' garment in the Baynes painting also differs significantly from those in the Jung family archive and the Red Book, perhaps a further indication that Jung designed it slightly later.

\section{THE RECONCILING SYMBOL: THE BLUE SPHERE AND THE CROSS-QUARTERED CIRCLE}

\section{The Blue Star-Sphere}

The blue spheres in Cat. 54 and Cat. 53 call to mind the 'round, glowing nebula of stars' that floated between $\mathrm{Ka}$ and Philemon in the lost painting described by Jung in Memories, Dreams, Reflections. They are undoubtedly related to the shining blue star of man, "who becomes through the principium individuationis', and is also 'the one God to whom worship is due'. The blue star/globe is the prime element in Jung's cosmology as first expounded by his soul on 16 January 1916, and appears in his sketch, and in Systema Mundi Totius nine months later (RB RE:578-579; Art:110, 178, Cat. 42; RB:364; Zervas 2019:183-184). In the 'Seventh Sermon to the Dead', written on 8 February 1916, Philemon had described this 'lonely star in the Zenith', 'the God and the goal of man', adding later in the autumn of 1917 that it is 'the blue starlight' of the black and golden seed, life as duration (RB RE:534, 536, italics added). It appears as an eight-rayed blue star in Red Book mandalas 84, 86-97 (autumn 1917-January 1919); then as particles that diminish in size and coalesce to form an egg-shaped, speckled blue background, interspersed with gold tesserae, similar in technique to Red Book 72 and 79, done before June 1917.

${ }^{21}$ The 'one who brought the sun' is Ka, as identified in the inscription of Red Book Atmavictu 122 mentioned above. For a discussion of Phanês imagery in The Red Book, see RB RE:358-359 and n. 211, and Zervas (2019). 
the small blue sphere and surrounding stars in the centre of mandala 105 discussed above; and as an eight-rayed star in the centre of Mandala 107, both done sometime between January 27 and March 21, 1919 (RB:105, 107).

\section{The Circle, Cross, and the Cross-quartered Circle}

Jung first developed the image of the cross-quartered circle in The Red Book. ${ }^{22}$ Its textual source is the overwhelming vision in 'Nox Tertia' witnessed by Jung's 'I' in the madhouse:

$[\ldots]$ the sun now rises in red glory, solitary and magnificent-in it is a cross from which a serpent hangs - or is it a bull, slit open, as at the slaughterhouse, or is it an ass? I suppose it is really a ram with a crown of thorns - or is it the crucified one, myself? (18 January 1914, RB RE:350).

It is a symbol of the synthesis of the opposites, and of individuation, which Jung later called an elemental mandala. As he commented in Memories, Dreams, Reflections:

The imagination attempts to sketch the image of the invisible as something which stands behind the phenomenon. I am thinking $[\ldots]$ of the simplest basic form of the mandala, the circle, and its simplest division, the quadrant, or [...] the cross. (Jung/Jaffé 1963:367-368).

Significantly, Jung introduced the circle and the cross in the elaborate historiated initial at the beginning of 'Mysterium', where his 'I' encounters Elijah, Salome, and the snake (RB:HI v (r)). Jung placed a small golden cross over Elijah, and in the blue-rayed shield in the lower left border; and a gold circle over Salome, and in the centre of the red cephalopodic form on the lower right border. They symbolise the opposites of foresight/Logos/masculine and feeling/Eros/feminine, which need each other and must be united (RB RE:177 n. 161, 179-83). ${ }^{23}$

\footnotetext{
${ }^{22}$ The cross-quartered circle is constructed from a circle divided into quarters by two of its diameters that intersect each other at 90 degrees, forming an equal-armed cross, usually on the horizontal and vertical axes. See the amplification with numerous line drawings by Dr William Barret and Jung in the Dream Analysis seminars (Jung 1984:340-388).

${ }^{23}$ See also Éveno 2015:18-21.
} 


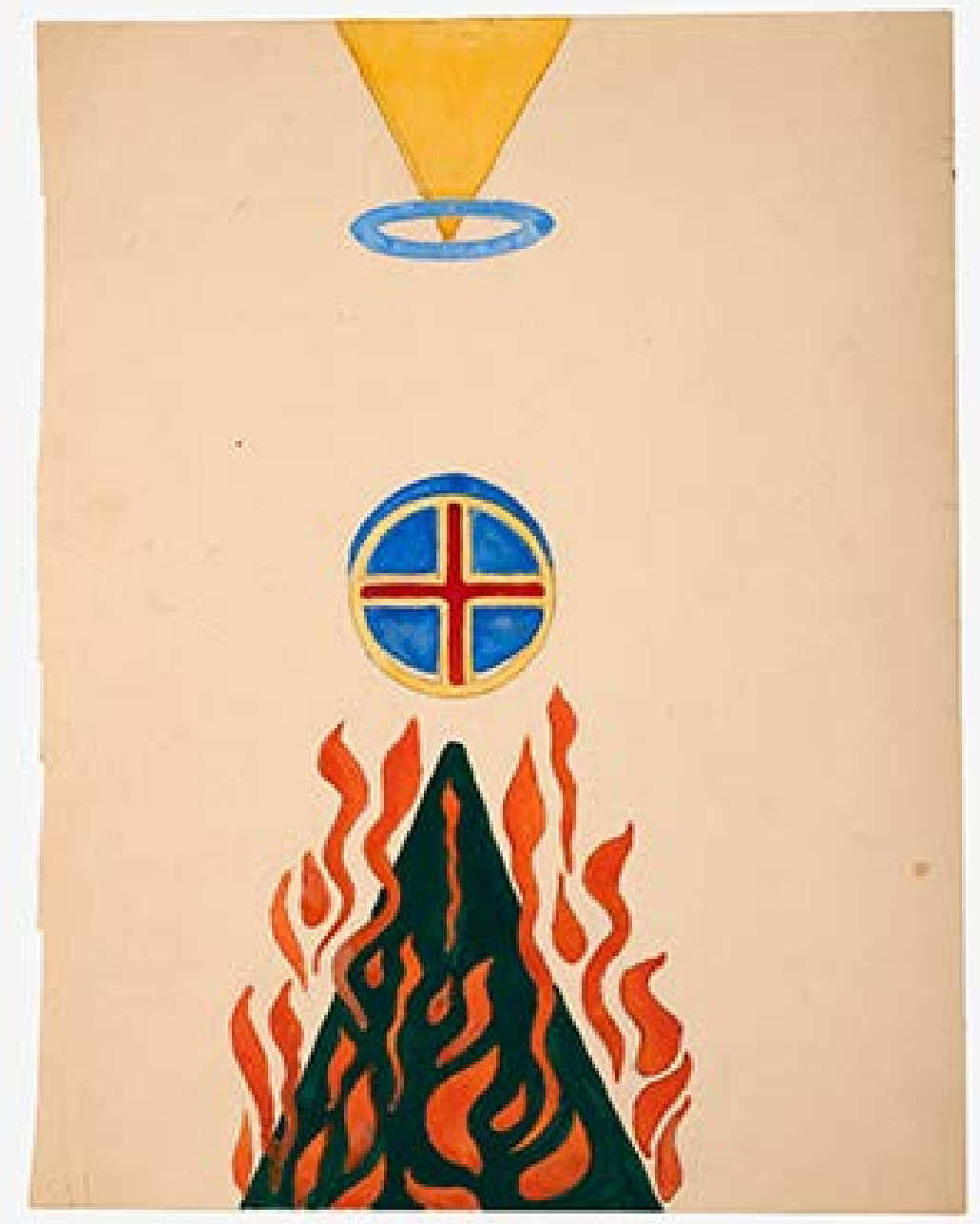

Fig. 5. Spheric Vision VI, 1919. Art, Cat. 61. (C) The Foundation of the Works of C.G. Jung, Zurich. 
The circle and cross next appear together as a cross-quartered, goldwinged, sun disc in 'Dies II' in Liber Secundus, where it is one of several symbols of rebirth (RB:HI 22). Both were done in the autumn of 1915.

Sometime during 1919, the same year that he created Red Book mandala 105, Jung had a series of visions featuring a sphere, which he then painted. They include an eight-rayed blue star, and a blue sphere circumscribed by a gold cross-quartered circle, whose arms are highlighted in red or decorated with red and blue mosaics (Art:137 and Cats. 56-61). Their design is close to the cross-quartered blue sphere in Cat. 54 (Fig. 3), probably done at about the same time. In Cat. 61 (Fig. 5), Jung interpreted the $\mathrm{Ka}$ and Philemon energies necessary to achieve individuation more abstractly. Chthonic Ka is symbolised by an upright black cone with red flames at the bottom of the painting; spiritual Philemon by a descending yellow cone at the top, whose apex penetrates a blue circle. ${ }^{24}$ The energic field generated between them produces the reconciling symbol: the blue sphere, circumscribed by a gold cross-quartered circle with red arms. Jung subsequently included it in Red Book paintings between 1920 and $1925 .^{25}$

\section{AMOR TRIUMPHAT, 1920-21: REDEMPTION THROUGH THE LAW OF LOVE}

But God will come to those who take their suffering upon themselves under the law of love, and he will establish a new bond with them (RB RE:354 n. 203, italics added).

In his Red Book painting 127, Amor Triumphat (Love Triumphs) (Fig. 6), Jung chose the reconciling symbol of the cross-quartered circle as the vessel best able to synthesise the major themes that had emerged in Liber Novus and were then conceptually developed in

\footnotetext{
${ }^{24}$ They are thus related to the upper and lower sun cones that feature significantly in Jung's imagery beginning with the runes in Black Book 7 (October 7, 1917) and RB Images 89, 93, 94 (RB RE:325-327).

${ }^{25}$ It appears in RB 107; in the architrave in the floating temple in 123 (4 January 1920), over the blazing sun-disc in the upper section of 125 (25 January 1920), 127 (9 January 1921), HI 136 (late 1922-early 1923), and multiple times in the border of Jung's Philemon, including directly below his temple, where a gold circle enclosing a red cross against a blue background floats above a gold crescent, with symbols for fire and water (elemental opposites) issuing from cones on either side (late 1924/1925, RB 154). See also Cat. 52 (Art 2019:130).
} 
Psychological Types, particularly in Chapters II and V (1921). ${ }^{26}$ Begun in May 1920, when Types was finished, Jung only completed Amor Triumphat on 9 January $1921 .{ }^{27} \mathrm{He}$ designed a separate iconic image for each section of the cross-quartered circle, setting them against a background of coloured opposites: blue arabesques on a red field. The inscription below the painting attests to the pain it had caused him:

[...] It expresses I know not what kind of grief, a fourfold sacrifice. I could almost choose not to finish it. It is the inexorable wheel of the four functions, the essence of all living beings imbued with sacrifice (RB RE:381 n. 240, italics added).

Unlike Jung's 1917 mandala sketches and related paintings in The Red Book, and his patients' mandalas that document the personal process of individuation and assimilation of the four psychological functions, Amor Triumphat is a multi-layered opus that presents a vision of the collective process of mankind and cultural history, integrated with the personal process of individuation, including that of Jung. ${ }^{28}$ The functions in Amor Triumphat are wounded gods that, having once been dominant, needed to be sacrificed. Jung had expressed this in the mantic section of 'Splitting of the Spirit':

Everything that becomes too old becomes evil, the same is true of your highest. Learn from the suffering of the crucified God that one can also betray and crucify a God, namely the God of the old year. If a God ceases being the way of life, he must fall secretly. (RB RE:160).

Once sacrificed, the gods remain repressed in the collective unconscious. ${ }^{29}$ ${ }^{26}$ See Shamdasani (2003:68-81). Galipeau (2013), Odajkyk (2013), and Beebe (2017:167-80) have written on aspects of Jung's typology and The Red Book.

${ }^{27}$ Jung's preface to Psychological Types is dated 'Spring, 1920' (1921, CW 6:v).

${ }^{28}$ The 1917 mandala sketches and related Red Book mandalas document the 'metabolism in the individual' ('Stoffwechsel im Individuum') necessary for the birth of the self and the new god, Phanês, in Jung (Zervas 2019). For his later mandala studies, see Jung (1929, CW 13:§§1-84; 1934/50, CW 9, 1:§§525-626; 1950, CW 9, 1:§§627712, and 1955a, CW 9, 1:§§713-718).

${ }^{29}$ In Psychological Types, Jung agreed with Schiller that 'culture, i.e. [...] the differentiation of functions' was responsible for the individual's differentiation. Moreover, 'breaking up of the harmonious co-operation of the psychic forces that exists in instinctive life is like an ever open and never healing wound, a veritable Amfortas' wound; since the differentiation of one function among several inevitably leads to the overgrowth of the one and to neglect and crippling of the rest': (Jung 1923:90-92, italics 


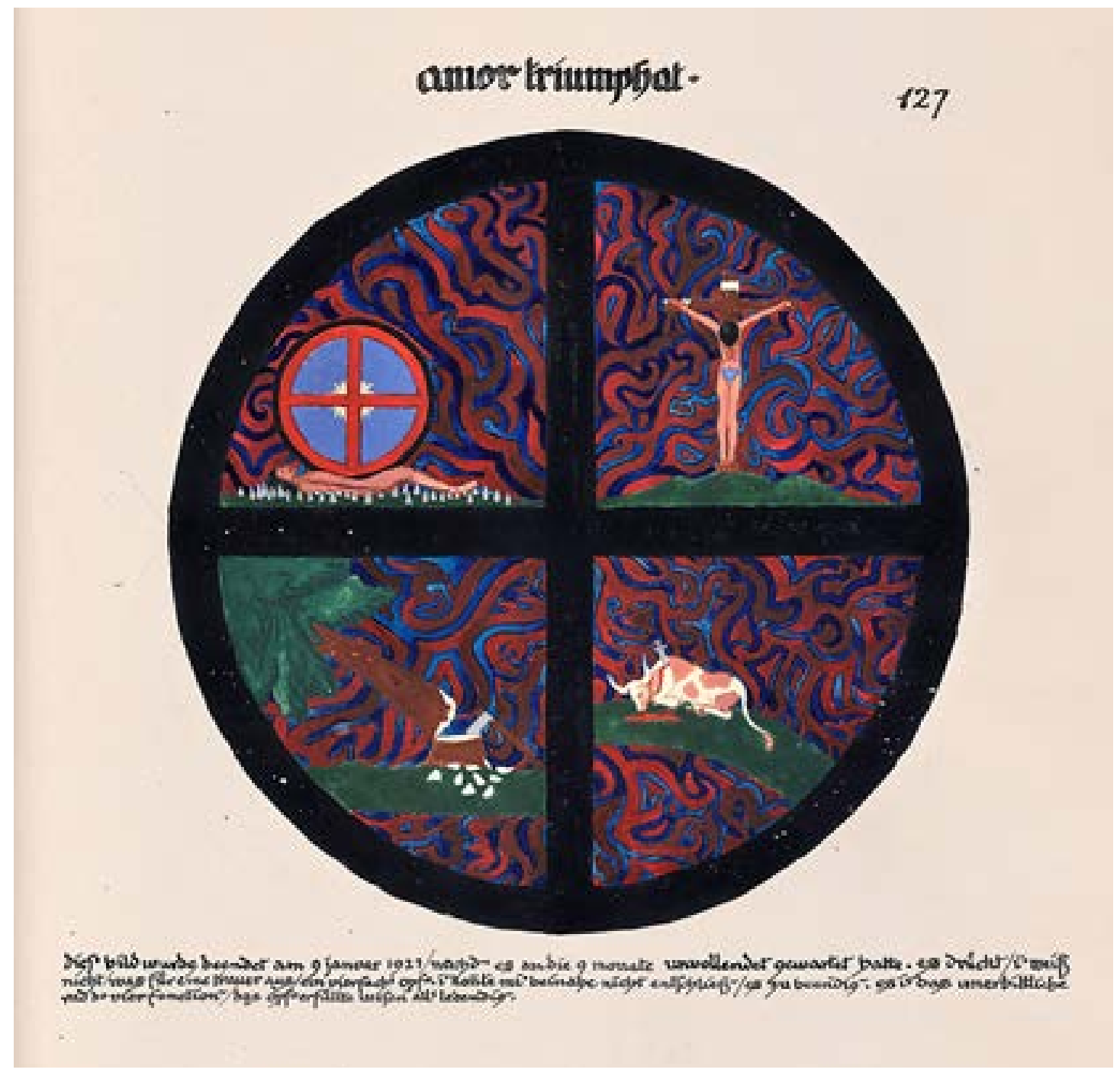

Fig. 6. Amor Triumphat, RB 127, May 1920-January 1921. C used by permission of the Foundation of the Works of C.G. Jung, Zurich. First published by W.W. Norton, New York, 2009. Used with permission of the publisher, W.W. Norton \& Company, Inc. All rights reserved. 
Modern individuals (and Jung) must acknowledge their sacrifice, and come to terms with them, in order to reconcile the dominant and repressed opposites (Jung 1921, CW 6:\$115). Hence Jung employed black-a colour of grief and mourning-for the outlines of the cross-quartered circle. Reintegration of the repressed gods is necessary for individuation, and for the creation of the new god through Man in the coming age. ${ }^{30}$

In 'Nox secunda', Jung had explained that one 'should have reverence for what has become, so that the law of love may become redemption through the restoration of the lower and of the past [...]' (RB RE:346, italics added). This occurs through the reconciling symbol produced by the transcendent function, as Jung himself had experienced during the years of Liber Novus, and subsequently explained (Jung 1916c, CW 8:§§131-193; 1916b:417, 436, 441; 1921, CW 6: $\$ 184)$. Amor Triumphat is Jung's visual depiction of Christianity's contemporary limitations, and a solution for the individual and religio-cultural future of western mankind. By continuing to honour and augment the law of love (RB RE:345-346, 353, 370), 'Love Triumphs'. In the painting, Jung succinctly illustrates the argument that he would present two years later at the Polzeath seminars in Cornwall: ecclesiastic Christianity had repressed one's relation to nature, the animal, inferior man, and creative fantasy (Jung/Harding 1923:16-18, italics added).

\section{The 'four-fold sacrifice'}

In the lower left quadrant of Amor Triumphat, a pine tree has been nearly felled by the axe imbedded in its trunk, its wood chips scattered around the horizontal strip of grass. This icon denotes the pre-Christian era when men worshiped vegetation gods. ${ }^{31}$ The partially axed tree signifies man's sacrifice of nature - the sensation function (green in Liber Novus and Jung's later works) necessary for adaptation to ecclesiastic

added; worded slightly differently in 1921, CW 6: §105-107).

30 This process was described by Jung in a letter to Joan Corrie on 29 February 1919 (RB RE:535 n.123).

${ }^{31}$ In 'Psychology of the Unconscious', Jung amplified the myth of Attis, the son-lover of Agdistis-Cybele who, driven mad by his mother's incestuous love, castrated himself under a pine-tree. In an annual ritual, his effigy was hung on a garland-decked pine tree, which was then cut down and taken into Cybele's cave. Jung noted that in some versions, Attis was equated with the pine tree, and cited an antique bas-relief where Attis grows out of a tree, symbolising the "life-principle" of vegetation inherent in the tree': (1912:401-402, revised with a different interpretation in 1956, CW 5:§§659-662). By depicting an axed pine tree in Amor Triumphat, Jung may thus also have alluded to Attis's symbolic castration. 
Christianity. ${ }^{32}$ It was also a function that Jung had sacrificed in himself. In the lower right quadrant, a bull lies wounded on the ground, pierced by the sword between its shoulder blades, its blood pooling on the arc of grass. This icon represents the pre-Christian era of animal worship. The wounded Mithraic bull symbolises man's sacrifice of his animal nature that occurred during the Christian period: the sacrifice of the feeling function (red/blood), which Jung had also undergone, and was forced to acknowledge and redeem in Liber Novus. ${ }^{33}$ In Psychological Types, Jung presented the self-castrated Origen as an example of the sacrificium phalli in service of the Christian process (1921, CW 6:\$§2124). In nature, a castrated bull is an ox, a domesticated beast of burden. ${ }^{34}$

\footnotetext{
${ }^{32}$ Interpreted as a symbol of the libido sacrificed/castrated to the Terrible Mother in The Psychology of the Unconscious (Jung 1912: §§681-682; revised 1952, CW 5:§659). In Liber Novus, Jung noted that the Germanic tribes sacrificed their trees and nature gods when they converted to the Christian religion, concluding: '[...] their life force bade them to go on living, and they betrayed their beautiful wild Gods, their holy trees and their awe of the German forests' ('Murder of the Hero', Layer 2 [1914] in RB RE:163). In Scrutinies, Philemon critiques these deeds: 'What did they do with the admirable tree? [...]would they have raised a murderous hand against their brothers if they had had worshiped the holy trees? ([1917], ibid:527). He gives a summary of his argument in a letter to Oskar Schmitz in May 1923: 'every step beyond the existing situation has to begin down there among the truncated nature-demons [...]. We must dig down to the primitive in us, for only out of the conflict between civilized man and the Germanic barbarian will there come what we need: a new experience of God' (Jung 1973:39-40). During the Polzeath seminar in July 1923, he noted that when nature is repressed, it first manifests itself as a 'nature demon', a 'Tree', 'The Noumen of the tree', and at a later state of historical development, as nature gods, 'particularly important because it was at this stage that the religious development of the Germanic peoples was cut down', and 'Christianity was grafted onto the stump' (Jung/Harding 1923:11, 16-17, 22). Such associations suggest that Jung may also have alluded to Matthew 3:10 in connection with the axed tree in Amor Triumphat: 'And now also the axe is laid unto the root of the trees: therefore every tree which bringeth not forth good fruit is hewn down, and cast into the fire'. My thanks to George Bright for posing the possible relevance of this verse.

${ }^{33}$ Mithras sacrificed the bull by slitting its throat, as discussed by Jung in The Psychology of the Unconscious (1991:§§688-691; 1921, CW 6:§§659-667, and Plate XL). Here, as in the other scenes of Amor Triumphat, the wounded bull symbolises the wounded god, rather than the sacrificial act itself, and hence represents the Mithraic bull. In his 1941 'Transformation Symbolism in the Mass', Jung stated that the 'Mithraic sacrifice is essentially a self-sacrifice, since the bull is a world bull and was originally identical with Mithras himself' (1941:293; revised and expanded in 1954, CW 11:§342).

34 Jung's 'I' witnessed oxen among the 'pressed multitude' of the dead in 'Death' (RB RE:264). The theme of man's repressed animal side occurs repeatedly in Liber Novus: in Scrutinies, Philemon commented: 'Where is the atonement for the 7,777 cattle whose blood they spilled, whose flesh they consumed? [...] would they have raised
} 
In the upper right quadrant, a man hangs crucified on a three-peaked mound, wearing a blue loincloth, blood dripping from his wounds. This icon depicts Christ, the son of God who willingly sacrificed himself for man's redemption..$^{35}$ It symbolises man's sacrifice of the thinking function (blue in Jung's colour symbolism) in the service of Christianity. In Psychological Types, Jung presented Tertullian (with whom he closely identified) as an example of the sacrificium intellectus. ${ }^{36}$ However, by splitting himself from the Devil, Christ had rejected his 'inferior brother': evil and the inferior man were repressed. Hence the God-man must also be sacrificed to make way for the birth of a new god, suitable for the post-Christian age. ${ }^{37}$

This is the subject of the upper left quadrant, where a man (similar to Jung's 'I' in The Red Book) lies bleeding on a 'bed of nails' scattered around the four-curved section of grass. His torso and lower body bend beneath the weight of a red cross-quartered circle enclosing a blue sphere, whose outer circumference is rimmed in black, repeating that of the framing circle. A central star is hidden behind the intersection of the cross bars, but its rays emanate outward: man's far-off and solitary star and the 'one god' a murderous hand against their brothers if they had atoned for the ox with the velvet eyes? (ibid:335-347, 377-378, 391). In 'The Role of the Unconscious', Jung reiterated that Christianity had suppressed the animal element in man, using a patient's dream of an injured bull (1918, CW 10: $§ 31)$. In the Polzeath seminars, he argued: 'the animal is replaced in the same way as is nature [...]. As a brother of man the animal is a function of man [...]. The repressed libido for animal relationship is living in the unconscious [...]. [It] animates divine images of a historical nature in dreams, when the dream speaks of animal it does so instead of saying divine' (Jung/Harding 1923:17, 20-24). In the Visions seminars (1930-1934), he described the sacrificial bull as an 'antique god' that represents an 'inferior feeling, an emotional condition', a divine metaphysical transcendent principle, which can be symbolized as a god in the form of an animal' (1997, 2:1112-1115). Writing before the publication of Liber Novus, Paul Bishop emphasised the Nietzschean and Thus Spoke Zarathustra overtones in Jung's early (pre1913) Dionysian conviction that the 'animal' instincts needed to be recuperated from their suppression during the Christian era in order to 'activate the whole man' (1995:6168; 2002:123-125). See also Bishop (2017:182-195); Domenici (2019:197-202).

${ }^{35}$ Jung remarked in the Visions seminars: 'The Christian cult had the great spiritual advantage over the Mithraic cult that it sacrificed not only the animal part, but the human-divine man in the form of Christ, which meant that the divine man as well as the animal man should be sacrificed.' (ibid, 1:218).

${ }^{36}$ Tertullian's sacrifice 'forced him to recognize the irrational dynamis of his soul as the foundation of his being' [i.e. creative fantasy] (1923:21-23); differently worded in 1921, CW 6:§§17-21).

37 The Spirit of the Depths prophesied the birth of Jung's new god in the mantic verses of 'The Conception of the God' (RB RE:165-166). The Christification of Jung's 'I' In 'Mysterium. Resolution' prepared him to become its birth-giver: 'I saw the death of Christ and I saw his lament; I felt the agony of his dying, of the great dying' [...] I am made into Christ, I must suffer it. Thus the redeeming flows' (ibid:204, 206). 
(RB RE:580). An icon of the individuated man, this is Jung's vision of the coming era. ${ }^{38}$ Having sacrificed Christianity's god-image, recognised evil, and redeemed his inferior self and other repressed functions, Man-Jungwillingly suffers so that the gods can be born through him and made human:

When the God enters my life, I return to my poverty for the sake of the God. I accept the burden of poverty and bear all my ugliness and ridiculousness, and also everything reprehensible in me $[\ldots]$ with this I prepare the way for the God's doing ('Nox Quarta', ibid:366-367). ${ }^{39}$

This process has occurred through creative fantasy, the intuitive function that was only partially repressed during the Christian era, but continued as a procreative power in the unconscious, where it conceived the future reconciling symbol that would be born into consciousness by the transcendent function, through individuation (Jung/Harding 1923:24).

Although Amor Triumphat envisions a totality, it is also 'the inexorable wheel of the four functions', 'the essence of all living beings', which will continue to rotate. In 'The Way of the Cross', Jung had reflected:

[T] he soul of humanity is like the great wheel of the zodiac that rolls along the way $[\ldots]$. There is no part of the wheel that does not come around again [...]. For these are all things which are the inborn properties of human nature. It belongs to the essence of forward movement that what was returns. [...] The meaning

\footnotetext{
${ }^{38}$ Its origins may be a dream that Jung had prior to 9 February 1914, which he mentions in 'The Magician' $\{5\}$ : 'I saw my body lying on sharp needles and a bronze wheel rolling over my breast crushing it. I must think of this dream whenever I think of love' (RB RE:437). Jung wrote in the Draft of Layer 2 of 'Divine Folly': '[Christ's] own way led him to the cross for humanity's own way leads to the cross. My way also leads to the cross, but not to that of Christ, but to mine, which is the image of the sacrifice and of life.'(ibid:332 n. 164). The 'image' is the reconciling symbol—of sacrifice and life-weighing on man's chest in this section of Amor Triumphat. Significantly, in the revised edition of Psychological Types, Jung added the following amplification to his original discussion of Christ carrying his Cross, as Mithras carried his bull, to the place of sacrifice: 'The cross, or whatever other heavy burden the hero carries, is himself, or rather the self, his wholeness, which is both God and animal — not merely the empirical man, but the totality of his being, which is rooted in his animal nature and reaches out beyond the merely human to the divine. His wholeness implies a tremendous tension of opposites paradoxically at one with themselves, as in the cross, their most perfect symbol' (1950, CW 5:\$460); it provides a late exegesis of this quarter of Jung's painting and the reconciling symbol.

${ }^{39}$ See also Jung's discussion in Scrutinies (ibid:534-536, 548).
} 


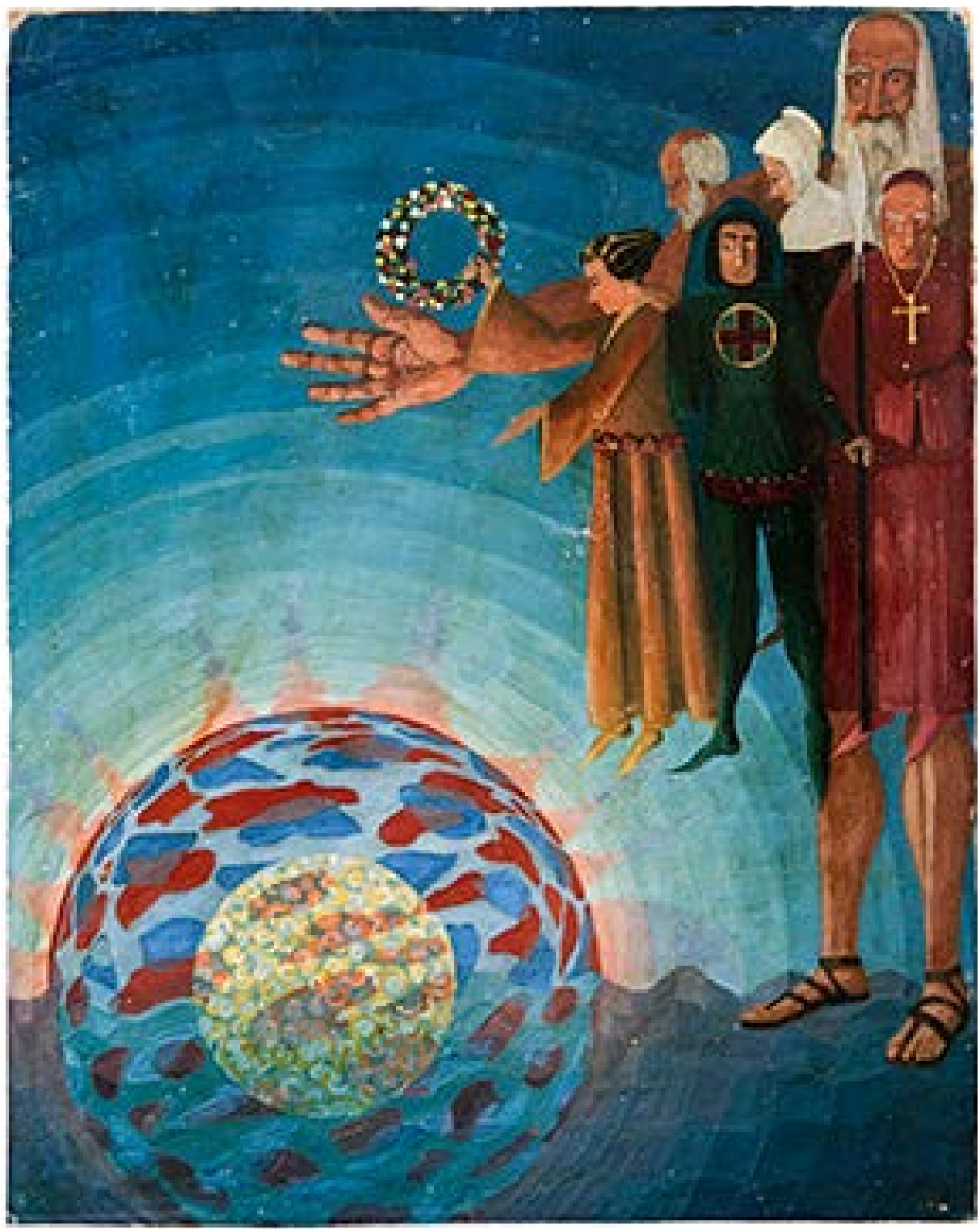

Fig. 7 . 'We Fear and We Hope', ca. 1920-23. Art, Cat. 66. Private collection (C) The Foundation of the Works of C.G. Jung, Zurich. 
lies in the manner and the direction of the recurring creation'

(RB RE:394, italics added). ${ }^{40}$

\section{'WE FEAR AND WE HOPE': THE GRAIL AND THE REDEMPTIVE FEMININE VESSEL}

The cross-quartered circle also features in Cat. 66 (Art:147), which, based on style, Jung probably painted sometime between 1920 and 1923. ${ }^{41}$ A gold circle inscribed with a red cross on a green background decorates the chest of the hooded figure who is clearly Parsifal, holding the holy spear (Fig. 7). ${ }^{42}$ Placed between four other figures, they float before the right arm of the monumental 'father' Philemon.

The conceptual background to the painting is sketched in Psychological Types. Jung interpreted Wagner's Parsifal in terms of the suffering caused by the tension of the opposites represented by the Grail (the 'light, celestial, feminine') in the keeping of Amfortas, and the power of Klingsor, the magician who had stolen the holy spear (the 'dark, earthly, masculine') and kept Kundry (instinctive life-force and the libido lacking in Amfortas) under his spell. The innocent Parsifal, free from the opposites, rescues the Kundry-libido from its 'state of restless, compulsive instinctuality', thereby becoming a 'deliverer, the bestower of healing and renewed life-force, the reconciler of the opposites'. When he reunites the Grail and holy spear at the end of the opera, Kundry dies, which Jung interprets as libido liberated 'from its naturalistic, undomesticated form', thereby enabling energy to erupt as a new stream of life, symbolised by the glowing Grail. ${ }^{43}$

Jung linked the Grail with Gnostic vessel symbolism (1921,

\footnotetext{
${ }^{40}$ This is also related to the twelve strokes of the world clock that Jung's 'I' heard after witnessing the red sun with an inscribed cross and its successive sacrificial victims (snake, bull, ass, ram, the crucified one, myself) in 'Nox Tertia', an anticipation of the imagery in Amor Triumphat (ibid:350-351).

${ }^{41}$ Jung's exquisitely layered technique for the globes and surrounding rings is particularly close to Red Book 129 (begun before 9 January 1919), 131 (between January 1919 and 1922), and 135 (completed 25 November 1922). See Mellick for a masterly analysis of Jung's painting mediums and techniques (2018:222-398, 2019:217231). At some point Jung gave the painting to Toni Wolff, and after her death he signed it 'AD 1923 Jung.sig. 1953' (Art:147).

42 The Grail knight whom Jung encounters in an early dream before his break with Freud wears a red cross on the front and back of his white tunic (Jung/Jaffé 1963:160).

43 Jung, 'The Significance of the Uniting Symbol' (1921, CW 6:§§371-372).
} 
CW 6:\$396, 401, 409), and to the relativity of God in man (i.e. God as a psychological value), which enables regression to a primitive condition that 'keeps man in touch with Mother Earth' (ibid:\$415). After discussing the late $13^{\text {th }}$ century German mystic, Meister Eckhart, and his concept of God in the human soul, Jung turns to the soul (anima) as perceived in analytical psychology: a personification of unconscious contents, the birthplace of God, and 'a creative function [that] gives birth to its dynamis in form of a symbol (ibid:§§416-426 ).

In Jung's painting, Parsifal bears the reconciling symbol on his tunic. He holds the reclaimed spear that has healed Amfortas in his left hand. ${ }^{44}$ An elderly 'cleric' stands to his left, dressed in a red cassock and scull-cap, his Latin pectoral cross a symbol of the outmoded ecclesiastical Christian era. He may be 'the red pope' cited in Long's summary as related to $\mathrm{Ka}$, the devil's brother, and the Antichrist (Appendix B). A white-bearded man and wimpled woman are positioned behind Parsifal on either side: the exact identification of these three figures remains unclear. ${ }^{45}$

The female figure to Parsifal's right, however, appears to be the redeemed Kundry; he places his hand encouragingly on the nape of her neck. Jung has clothed her in opposites: a simple earth-toned garment that is belted by a garland of roses, a flower associated with feminine spirituality. Kundry is clearly energised, associated not with her death in Wagner's opera, but with the Grail's 'newly-streaming life' (Jung 1923:270, slightly differently worded in 1921, CW6:§371). Thus Kundry represents the soul-image or anima, whose daemonic and divine aspects have been reunited by her redemption. ${ }^{46}$ This identification is confirmed

\footnotetext{
${ }^{44}$ In Liber Novus, the pictorial motifs of grail- and spear-like elements first appear in the historiated initial for 'Splitting of the Spirit' (1915, RB:HI iv (r), then in the sketch and painting of Systema Mundi Totius (1916, ibid:364; Art:178). The Grail legend became Emma Jung's particular subject of research, hence Jung's limited treatment of the theme (Protocols:308, Jung/Jaffé 1963:205). For Emma's work, cut short by her death in 1955, see Jung /von Franz (1970 [1960]). See above, note 29, for the reference in Psychological Types to Amfortas's wound as symbolic of the differentiation of functions needing to be healed.

${ }^{45}$ It is possible that the elderly pair represent Herzeleide, Parsifal's widowed (wimpled) mother, and Gurnemanz, the Grail knight he meets at the beginning of Wagner's opera, and who later becomes his mentor. However, this would not explain the presence of the 'cleric' figure, or of Philemon; nor do these figures relate easily to the narrative description of the Parsifal play as it unfolded in 'Nox Quarta' in Liber Novus (RB RR:363-364).

${ }^{46}$ In various versions of the Grail legend, Kundry is the mysterious and sinister Grail messenger, a seductress, or a penitent, and also a serpent-like being, as interpreted by Wagner's reading of Carlo Gozzi's $18^{\text {th }}$ century play La Donna serpent: see Kinderman (2003:47-49, 2005:13-19).
} 
by her profile and hairdo, which are identical to those of the two anima bird-women in Cat. 54 (Fig. 3), the kneeling women in Cat. 53 (Fig. 4), and a painted wooden bust of a blue-eyed, black-haired woman carved by Jung at around this period, later described as his anima (Art:107, Cat. 39).

The drama intimated, but not yet realised, in the painting pivots around the enigmatic inscription Jung penned on the verso, which was probably his own, as it relates to the painting, rather than to any identifiable literary source:

We fear and we hope: will you sacrifice the laurel of eternity to the bridal expectant earth? our feet stand in the void and are granted no beauty and fulfilment. will the promise be broken? will the eternal marry the temporal? (Art:147).

All five protagonists are indeed suspended in mid-air. Philemon stares into the future, his open hand gesturing towards the two spheres half embedded the watery depths below his feet. Parsifal and the 'cleric' gaze down apprehensively, but Kundry and the two rear figures have turned to face the spheres. Kundry raises a multi-coloured wreaththe 'laurel of eternity' - in her right hand. Kundry-as-anima, as a psychological function of man able to mediate consciousness and the unconscious, is poised to sacrifice this symbol of the greatest value to the 'bridal expectant earth' in order to liberate the newly formed symbol below. ${ }^{47}$ By marrying the eternal, figured as the giant blue globe decorated with red and overlapping dark blue forms, and the temporal, figured as the smaller translucent sphere hovering before the blue one, teeming with multi-coloured squiggles of life, ${ }^{48}$ the anima would unite

\footnotetext{
${ }^{47}$ In 'The Relations Between the Ego and the Unconscious', Jung described the transformation of the anima from an autonomous complex into a function of relationship between the conscious and the unconscious; when achieved, the anima is 'no longer Kundry, daemonic Messenger of the Grail, half divine and half animal' 1928:§374. See Jung/ von Franz (1970 [1960]:112, 113-141, 205).

${ }^{48}$ Careful examination of the spheres confirms that Jung first painted the large blue sphere, then decorated it with the red forms, and then the blue, sometimes overlapping ones. He painted the watery 'waves' over the lower half of the blue sphere. Then the smaller sphere was made, using translucent pigments. The red spots on the blue globe, and the eleven orange rays circumscribing its upper 'risen' half, rising through six or seven of the surrounding circular atmospheric rings, could also be Jung's visual elaboration of an earlier dream he recorded on 17 January 1917, where he referred to Incantation Image 58 (painted on the same date), red sun spots then present on the sun, and, in his dream, a tongue of fire that begins to eat the dome of the 'seven blue heavens' ( RB RE:302 note 129).
} 
the above and below, God and man. ${ }^{49}$ The painting is poised on the brink of action, but its outcome remains unknown: 'we fear and we hope'.

However, the unresolved drama in the painting also alludes to Jung's intuition that man's quest for the Holy Grail conceals a precious secret that, in Memories, Dreams, Reflections, he first dated to his youth, and subsequently linked with his alchemical studies of the exiled philosophers' stone, unam vas, unus lapis (Jung/Jaffé 1963:160-161, 262-264). In the unpublished Protocols, Jung likened the eternal quest for the 'unfindable' Grail with the secret of individuation, a necessarily incomprehensible mystery, and an 'inner process of dying before surrendering oneself' (Protocols:308-309; see Kingsley 2018:110, 140; Bishop 2019:424).

In another passage from Memories, Dreams, Reflections, Jung related the Christian hero Parsifal to the magician Merlin, his exiled dark brother, 'son of the devil and a pure virgin', who continues to roam the forest in an unredeemed form (Jung/Jaffé 1963:216). This parallel is more extended in the Protocols, where Jung stated that Merlin is for Parsifal, what Mephistopheles is for Faust: the dark 'brothers', necessary for wholeness (Protocols:211-212). Hence as pairs they are similar to Christ and the devil, his 'dark brother', good and evil requiring reconciliation in the new god, and to Philemon as the inverse of Christ and $\mathrm{Ka}$ as the devil's brother, the Antichrist (Appendix B). Most interestingly, Jung then brings in Philemon and $\mathrm{Ka}$, the magician and the one 'who makes things real', as 'the opposites brought together; hence the realisation of man and his shadow, the problem of the opposites. "I am both"! This is the result of incarnation' (the temporal united with eternity) (ibid:212). ${ }^{50}$ Might the sacrifice of the 'laurel of eternity' in Jung's painting be an attempt to redeem the vanished Merlin, thereby uniting the opposites of Parsifal and his dark brother, a marriage of the eternal and the temporal?

\section{LATER FORMATIONS: 1923-59}

Jung incorporated the cross-quartered circle into the design of the pavement for his round tower at Bollingen, also begun in 1923. One cross

\footnotetext{
${ }^{49}$ This links back to the soul's three-fold nature in Liber Novus and Black Book 5: 'I bind the Above with the Below. I bind God and animal' (RB RE:388-389 and n. 252; 577).

${ }^{50}$ For a useful summary of Jung's amplifications of Merlin, including Mercurius, see Jung/von Franz 1951:355-78. Shamdasani observes that Jung's 1948 essay 'The Spirit Mercurius' (1953, CW 13) is also a 'meditation' on Ka ('Art and Psyche' conference, April 2019).
} 
arm is aligned with the tower's original entrance and a window opposite, and the other with the hearth and another window, thus encircling and orienting the 'ground position' that supported his 'confession in stone', linked with the maternal hearth and Emma Jung (Protocols:157, 211, 297; MDR:212-224). ${ }^{51}$ In the mandala created for the wall of Jung's bedroom above, the cross-quartered circle forms the point of departure, generating the complex geometric figures and sixteen-pointed star that emanate outward (reproduced by Gaillard 1998:221). ${ }^{52}$ It was subsequently an essential element in Jung's 'mandala' therapy of the 1920s and '30s, and figures repeatedly in his studies on alchemy and later writings, particularly Mysterium Coniunctionis (1941-54) and Aion (1959). ${ }^{53}$

Most movingly, however, Jung immortalised the crossquartered globe and cross in two late commemorative works in stone. Within the pediment of the memorial he devised for his wife Emma Jung at Bollingen (1956), he created a sacred coniunctio (Fig. 8).

The cross-quartered sphere, Parsifal's emblem in Cat. 66, and a prime symbol for Jung and his life's work, rests on the upper rim of a chalice, symbol of the Grail, Emma, and her life's work. The following year, he employed it for the four corners of his design for the Jung family tombstone, erected at his death in 1961 (Fig. 9: Art:169-170, Cats. 78 and 79, 171, Cat. 80 and Fig. 60). The imagery in both also links back to the border of the Red Book Philemon: the crescent-vessel and cross-quartered globe below his round temple (Philemonis Sacrum, a reflection of Jung's tower), and the crossquartered circles that mark the painting's corners (RB 154; MDR:222 n. 5).

\footnotetext{
${ }^{51}$ The first tower originally had an earthen floor; Jung paved it when he decided to add the upper story, after 1923. The cross does not indicate the tower's geographical orientation. My thanks to Andreas Jung for providing this information.

52 Jung fashioned this mandala in the summer of 1928, in collaboration with Robert Edmond Jones, an analysand and friend who was a talented artist and stage designer who had resided in Küsnacht/Zurich ca. 1925/6-27 (Douglas 1993:145, 153, 155-156; Jung 1973:49, 71, 81), as we know from a letter Jung wrote to Christiana Morgan on 21 August 1928, sold at auction by Sotheby's in 2006 (Continental Books \& Manuscripts, 8 June 2006:Lot 19; personal communication, Sonu Shamdasani).

${ }^{53}$ In his later writings, Jung referred to the cross-quartered circle/sphere as the circulus quadratus or quadratura circuli (1936, CW 18: 1331; 1937b, CW 11:§§108, 125; 1953a, CW 12: $\$ 123,176,1955 \mathrm{a}, \mathrm{CW} 9,1: \$ 713)$. The terms were derived from alchemy, and did not refer to the ancient geometrical problem of 'squaring the circle', i.e. constructing a square with the same area as a given circle by using a compass and rule.
} 


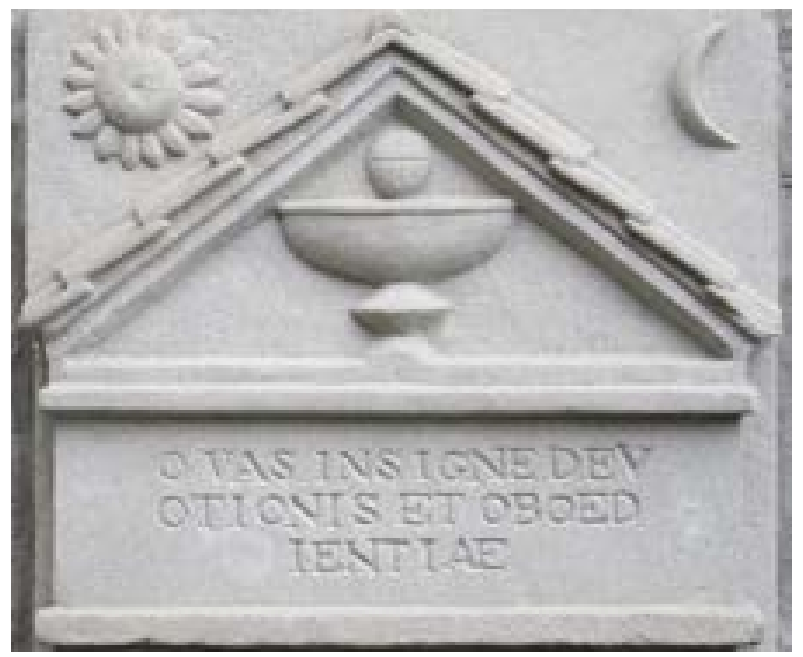

Fig. 8 . Emma Jung Memorial, 1955/56. Bollingen. (C) Diane Finiello Zervas, 2014.

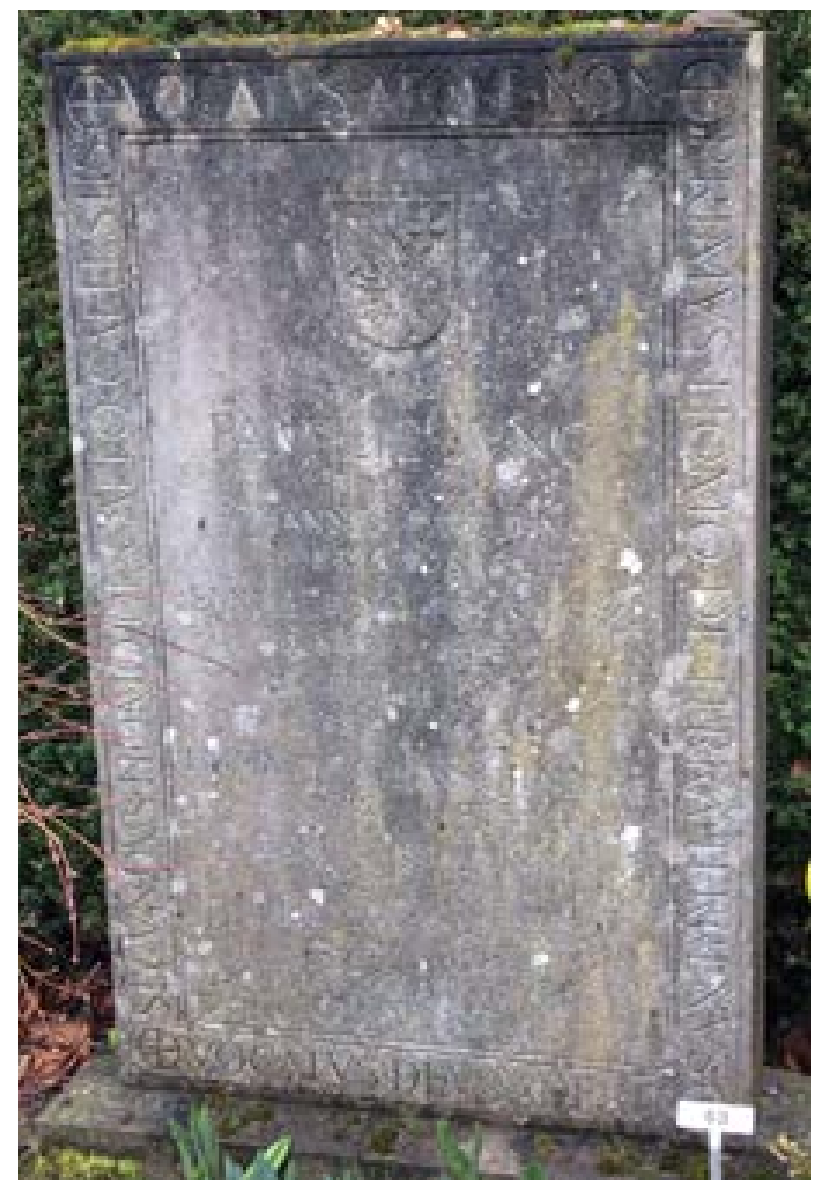

Fig. 9 . Jung Family Tombstone, 1957/61 Küsnacht. (C) Diane Finiello Zervas, 2017. 


\title{
CONCLUSION
}

By employing a contextual approach incorporating image and textual material, I have been able to identify the figures of Philemon and $\mathrm{Ka}$ in several Red Book paintings and newly published visual works by Jung that were developed concurrently or in response to Jung's visionary material from 1917. This has enabled me to document the visual formation of one of Jung's primary symbols of creative fantasy, the cross-quartered circle, as a product of the creative tension held between the two 'fathers', Philemon and $\mathrm{Ka}$, and to trace chronologically and historically the way it remained a 'living thing' for Jung, a container able to synthesise visually some of his core concepts, including individuation, the transcendent function, sacrifice, the grail and the redemptive feminine vessel.

The forthcoming publication of Jung's Black Books will undoubtedly reveal more about Philemon, Ka, and other personifications that he recorded and visually portrayed after the completion of Liber Novus. Meanwhile we can discover a great deal about their evolving attributes and interactions, and the creation and development of the reconciling symbol by studying Jung's extant visual works of 1919-1923, which document his pressing need - and ability - to form in matter the thoughts that his soul gave him, by means of Philemon's and Ka's abilities: intuition and sensation.

Diane Finiello Zervas

London 2019

dianezervashirst1@me.com

\author{
ABBREVIATIONS \\ Art $=$ The Art of C.G. Jung. 2019. \\ RB = Jung, Carl Gustav. 2009a. The Red Book. \\ RB RE = Jung, Carl Gustav. 2009b. The Red Book, Reader's Edition.
}

\section{REFERENCES}

The Art of C.G. Jung. 2019. Edited by the Foundation of the Works of C.G. Jung, eds. Ulrich Hoerni, Thomas Fischer, Bettina Kaufmann. Translated from the German by Paul David Young and Christopher John Murray. New York and London: W.W. Norton \& Company. 
Beebe, John. 2016. Energies and Patterns in Psychological Types. Abingdon, U.K./New York: Routledge.

Bishop, Paul. 1995. The Dionysian Self. Berlin and New York: Walter de Gruyter.

- 2002. 'The Holy Grail of Sexuality. Jung and Wagner's "Parsifal"'. Spring 69: 115-32.

- 2009. Analytical Psychology and German Classical Aesthetics. Goethe, Schiller, and Jung. Vol. 2. The Constellation of the Self. London and New York: Routledge Taylor and Francis Group.

-2017. On The Blissful Islands with Nietzsche \& Jung. In the shadow of the superman. London and New York: Routledge Taylor and Francis Group.

- 2019. Review of P. Kingsley, Catafalque: Carl Jung and the End of Humanity. Journal of Analytical Psychology 63 (3):423-7.

Domenici, Gaia. 2018. "Crush the Head of the Serpent and it will Bite you in the Heel": A Reconstruction of Jung's Interpretation of the Poisonous Serpents in Zarathustra Through Liber Novus'. Phanês $1: 1-27$.

2019. Jung's Nietzsche. Zarathustra, The Red Book, and 'Visionary'Works. London: Palgrave/Macmillan.

Douglas, Claire. 1993. Translate this Darkness. The Life of Christiana Morgan, the Veiled Woman in Jung's Circle. Princeton: Princeton University Press.

Éveno, Bertrand. 2015. 'Jung's "Multicolored Arabesques": Their Renderings and Intentions In The Pictorial Vocabulary Of The Red Book.' Psychological Perspectives. 58 (1):5-33.

Guillard, Christian. 1998. Le Musée Imaginaire de Carl Gustav Jung. Baume-les-Dames:Stock

Galipeau, Steven. 2013. 'The Red Book and Jung's Typology'. Psychological Perspectives. 56 (1):34-49.

Goethe, Johann Wolfgang von. 1976. Faust. A Tragedy. Translated by Walter Arndt and edited by Cyrus Hamlin. London/New York: W.W. Norton \& Company.

Hubbard, Arthur Jonh. 1916. The Authentic Dreams of Peter Blobbs and of Certain of his Relatives: Told by Himself with the Assitance of 
Mrs. Blobbs. London: Longmans.

Jung, C.G. [1912] 1991. The Psychology of the Unconscious. Translated by Beatrice M. Hinkle. London: Moffat, Yard and Company. Reprinted with an introduction by William McGuire. London: Routledge.

- [1916a]. Adaptation, Individuation and Collectivity. Collected Works of C. G. Jung. vol. 18: $\S \S 1084-1106$.

—. [1916b] 1917. 'The Psychology of the Unconscious Processes'. In Collected Papers on Analytical Psychology. Ed. Dr Constance E. Long. London: Baillière, Tindall and Cox: 352-444. - [1916c]. The Transcendent Function. Collected Works of C. G. Jung. vol. 8: §§131-93.

- [1918]. The Role of the Unconscious. Collected Works of C. G. Jung. vol. 10: $\S \S 1-48$.

—. [1921]. Psychological Types. Collected Works of C. G. Jung. vol. 6. 1923. Psychological Types or The Psychology of Individuation. trans. H.G. Baynes. London: Kegan Paul.

. [1928]. The Relations Between the Ego and the Unconscious. Collected Works of C. G. Jung. vol. 7: §§202-406.

- [1929]. 'Commentary on "The Secret of the Golden Flower", . Collected Works of C. G. Jung. vol. 13: §§1-84.

- [1934/50]. A Study in the Process of Individuation. Collected Works of C. G. Jung. vol. 9, 1: §§525-626.

- 1936. Psychology and National Problems. Collected Works of C. G. Jung. vol. 18: §§1305-1342.

1937a. Bericht über die Berliner Vortrage von Prof. Dr C. G. Jung. 28/29 September 1937. Ausgearbeitet von Frau Marianne Stark. Berlin. Unpublished. vol. 11 . 1937b. Psychology and Religion. Collected Works of C. G. Jung. [1941/55]. 'Transformation Symbolism in the Mass'. In The Mysteries. Papers from the Eranos Yearbooks. Ed. Joseph Campbell. Princeton: Princeton University Press: 274-336. . [1950]. Concerning Mandala Symbolism. Collected Works of C. G. Jung. vol. 9, 1: §§627-712. 
—. [1951]. Aion. Collected Works of C. G. Jung. vol. 9, 2.

- [1952]. Symbols of Transformation. Collected Works of C.G. Jung. vol. 5.

. 1953a. Psychology and Alchemy. Collected Works of C. G. Jung. vol. 12 .

1953b. The Spirit Mercurius. Collected Works of C.G. Jung. Vol. 13: $\S \S 234-303$.

- 1954. Transformation Symbolism in the Mass. Collected Works of C.G. Jung. Vol. 11: §§296-448.

- 1955a. Mandalas. Collected Works of C. G. Jung. vol. 9, 1: $\S \S 713-18$. vol. 14.

1955b. Mysterium Coniunctionis. Collected Works of C. G. Jung. 1973. Letters, vol. 1. Selected and edited by Gerhard Adler in collaboration with Aniela Jaffé. London: Routledge \& Kegan Paul. 1976. Letters, vol. 2. Selected and edited by Gerhard Adler in collaboration with Aniela Jaffé. London: Routledge \& Kegan Paul.

-1984. Dream Analysis: notes of the seminar given in 1928-30. Ed. William McGuire. London: Routledge \& Kegan Paul.

1989. Nietzsche's Zarathustra: notes of the seminargiven in 1934-9. 2 vols. Ed. James L. Jarrett. London: Routledge.

1. 1997: Visions: notes of the seminar given in 1930-4. 2 vols. Ed. C. Douglas. Princeton: Princeton University Press.

. 2009a. The Red Book: Liber Novus. Edited and Introduced by Sonu Shamdasani, Translated by Mark Kyburz, John Peck, and Sonu Shamdasani. New York/London: W. W. Norton \& Company. .2009b. The Red Book: Liber Novus. A Reader's Edition. Edited and Introduced by Sonu Shamdasani, Translated by Mark Kyburz, John Peck, andSonuShamdasani.NewYork/London:W.W.Norton\&Company.

- 2014. Dream Interpretation Ancient and Modern: Notes from the Seminar Given in 1936-1941-Updated Edition. Ed. by John Peck, Lorenz Jung, Lorenz, Maria Meyer-Grass. Transl. by Ernst Falzeder and Tony Woolfson. Philemon Foundation Series 9. Princeton: Princeton University Press. 
Jung, Carl Gustav/Harding, Mary Esther. 1923. Human relationships in relation to the process of individuation: "Cornwall Seminar" given by Carl Gustav Jung July 1923 Polzealth, Cornwall, England. Unauthorized notes by M. Esther Harding, 1-27. Yale University, Meinecke Library: New Haven.Consulted at: www.brbl-dl.library.yale.edu.

Jung, Carl Gustav / Jaffé, Aniela. 1971[1962]. Erinnerungen, Träume, Gedanken von C.G. Jung. Aufgezeichnet und herausgegeben von Aniela Jaffé. Ostfildern: Patmos Verlag.

_. 1963[1962]. Memories, Dreams, Reflections, tr. Clara and Richard Winston. London: Collins and Routledge \& Kegan Paul.

Jung, Emma/von Franz, Marie-Louise. 1986 [1970]. The Grail Legend. Trans. Andrea Dykes. 2nd edition. Boston: Sigo Press.

Kinderman, William. 2005. 'Introduction: The Challenge of Wagner's Parsifal'. In William Kinderman and Katherine R. Syer (eds.). A Companion to Wagner's Parsifal. Rochester, N.Y./ Woodbridge: Camden House.

2013. Wagner's Parsifal. Oxford: Oxford University Press.

Kingsley, Peter. 2018. Catafalque: Carl Jung and the End of Humanity. 2 vols. London: Catafalque Press.

Long, Constance E. 1919-21. Journal. B MS b62. Harvard Medical Library, Francis A. Countway Library of Medicine, Mass. Unpublished.

Mellick, Jill. 2018. The Red Book Hours, Discovering C.G. Jung's Art Mediums and Creative Process. Zurich: Scheidegger \& Spiess.

2019. 'Matter and Method in The Red Book: Selected findings', In The Art of C.G. Jung. Edited by the Foundation of the Works of C.G. Jung. Ulrich Hoerni, Thomas Fischer, Bettina Kaufmann (eds.). Translated from the German by Paul David Young and Christopher John Murray. New York and London: W.W. Norton \& Company.

Odajnyk, V. Walter. 2013. 'The Red Book as the Source of Jung's Psychological Types.' Psychological Perspectives 56 (3):310-28.

Pogson, Beryl. 1961. Maurice Nicoll. A Portrait. London, Vincent Stuart Ltd.

Protocols of the interviews conducted by Aniela Jaffé with C.G. Jung for Memories, Dreams, Reflections. Library of Congress, Washington, DC. 
Shamdasani, Sonu. 1995. 'Memories, Dreams, Omissions.' Spring. A Journal of Archetype and Culture 57: 111-32.

2003. Jung and the Making of Modern Psychology. A Dream of a Science. Cambridge: Cambridge University Press.

Zervas, Diane Finiello. 2019. 'Intimations of the Self.' In The Art of C.G. Jung. Edited by the Foundation of the Works of C.G. Jung. Ulrich Hoerni, Thomas Fischer, Bettina Kaufmann (eds.). Translated from the German by Paul David Young and Christopher John Murray. New York and London: W.W. Norton \& Company. 
APPENDIX A

Chronology of Jung's Fantasies and Visual Images Relating to Ka, Philemon, Ha and Reconciling Symbol Mentioned in the Text

Superscripted numbers indicate works reproduced in the article

DATE

1915 autumn

1915 autumn

191616 January

1916 after 15 October

c. 1917

c. 1917

191725 April

191720 May

1917 August-September

1917 October-1919 January

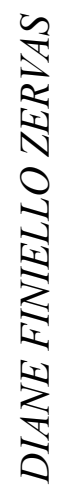

\section{SUBJECT/MEDIA}

Red Book HI v(r) Oand + Red Book HI $22 \oplus$

Systema Mundi Totius sketch

Systema Mundi Totius painting

Cat. 50 (Phanês)

Cat. 51 (Phanês)

Atmavictu genealogy 1

Atmavictu genealogy 2

Mandala sketches

Mandalas 80-97

Ha mentioned

$\mathrm{Ka}$ is the other side of $\mathrm{Ha}$

$\mathrm{Ka}$ is Philemon's shadow

Ka's temple: the gods' prison and grave

Spheric Visions $*$ *

Painting with kingfisher wing, $K a$, nebula of stars

\section{LOCATION}

REFERENCE

Red Book

Red Book

Black Book 5 Art of C.G. Jung Cat. 178

R. Hinshaw

Private Collection

Private Collection

Black Book 6:179ff

RB:364

Art of C.G. Jung

Art of C.G. Jung

Black Book 6:195 RB RE:372 n. 232

Jung Family Archive Art of C.G. Jung Cats. 81-105 Red Book

Black Book 7:9-10 RB RE:325-327

Black Book 7:25 ff. RB RE:373

Black Book 7:34 RB RE:373

Black Book 7:39 RB RE:372-374

Jung Family Archive Art of C.G. Jung, Cats. 56-61 lost

Protocols: 23-27, MDR:177 
${ }^{3}$ c. 1919 (before 15 X 1920) Painting with Philemon, Ka, $\oplus$

${ }^{4}$ c. 1919

c. 1919

1919 post 3 January

1919 post 3 January

1919 finished by April

${ }^{1} 191927$ January-21 March

${ }^{2} 1919$

1919 summer

1919 after summer

1919 autumn

19194 December

c. 1920

डิ ${ }^{6} 1920$ May-Jan 21

${ }^{7}$ c. $1920-23$

1923

$1924 / 25$

ca. $1925-1928$

c. 1928

${ }^{8} 1955 / 56$

${ }^{9} 1957 / 61$
Painting with Philemon, Ka, Phanês, $\oplus$

Painting with Philemon, $\oplus$, vessel

Winged Philemon: sketch

Winged Philemon: painting

Phanês

Philemon and Ka: Red Book Mandala

$K a$ wooden statuette

Atmavictu: 2 statuettes (London)

Atmavictu: stone statue

Atmavictu: as dragon in RB paintings

Atmavictu: Red Book painting

Wooden Bust of Woman

Amor Triumphat

Philemon, Parsifal, Kundry and Others

First Round Tower

Philemon: Red Book 154

Philemon mural

Mandala mural

Emma Jung Memorial

Jung Family Tombstone
Jung Family Archive Art of C.G. Jung, Cat. 54 Private collection Art of C.G. Jung, Cat. 53 Jung Family Archive Art of C.G. Jung, Cat. 52 1919 agenda Art of C.G. Jung, Cat. 64 unknown Art of C.G. Jung, Cat. 65

Red Book 113

Red Book 105

Jung Family Archive Art of C.G. Jung, Cat. 49 private collection

Küsnacht Art of C.G. Jung, Cats. 67-68 Art of C.G. Jung, Cat. 69

Red Book 117,119

Red Book 122

Jung Family Archive Art of C.G. Jung Cat. 39 Red Book 127

private collection

Art of C.G. Jung, Cat. 66 We Fear and We Hope'

Bollingen

Red Book 154

Bollingen not published

Bollingen Gaillard 1998:221

Bollingen

Küsnacht 


\section{APPENDIX B \\ Constance Long's summary of the discussion with Jung about his painting (Cat. 54) held on 15 October 1920 (Journal, 1920:31-37). ${ }^{1}$}

The circle in the distance has four colours twisted round it. This is ornament. Snake ornaments, and would become snakes if the personality should disintegrate. The four colours are the four functions. Each function consists of two sides, subjective and objective, external and internal-introversion and extroversion. These constituents of individuality are the principles of different ways in the development of the libido into the individual function of adaptation. The individual monad is a part of the great world, a drop of eternity. The two figures in either hand, snake and bird is the same anima split into halves. The picture represents the state of things in the unconscious. The anima takes on the quality of the things with which she deals - with those 'below' the snake or beauty creature, and those 'above' the bird or winged creature.

The two figures on either side are personifications of dominants $=$ 'fathers'. The one is the creative father, KA. The other, Philemon, the one who gives form and law (the formative instinct). Ka would equal Dionysus and Philemon $=$ Apollo. Philemon gives formation to the things within elements of the collective unconscious. It formulates backward not onwards. The onward formulation would be expressed as the child. The child is not represented within the picture. It is bound in the [centre] of that abstract child-circle. By that centre, and through it, via an invisible point you enter an enormous space, in which the child appears as a constellation in the great distance, i.e. in the future. The child is future. The child appears in the individual like a Cabir-man.

This is a 'perception', and not a formulated truth, but it resumes an enormous amount of individual experience, not only in myself but in my psyche. A woman had a dream of a Chinese monkish figure in a brown habit, on a pedestal inscribed 'what you think impossible'. She lifted this figure, and found inside a small china figure like a Christ child, only sitting with his legs like Buddha.

\footnotetext{
${ }^{1}$ I am grateful to Sonu Shamdasani for sharing his transcription of part of this entry with me, and to David Genty for allowing me to view a digital copy of Constance Long's Journal. Long's entries are made over several pages, some of which are her rough drafts (on the versos) of the final version on the rectos. My transcription has attempted to render the text readable, and therefore has expanded various abbreviations, etc.
} 
Philemon gives the idea, (maybe of a god) but it remains floating, distant and indistinct-because all the things he invents are winged. But Ka gives substance and is called the one who buries the gods in gold and marble. He has a tendency to imprison them in matter, and so they are in danger of losing their spiritual meaning, and become buried in stone. So the temple maybe the grave of god, as the Church has become the grave of Christ. The more the church develops, the more Christ dies. Ka must not be allowed to produce too much-you must not depend in substantiation; but if too little substance is produced the creature floats.

The transcendent function is the whole - not this picture, nor my rationalisation of it, but the new and vivifying creative spirit that is the result of the intercourse between the conscious intelligence and the creative side. $\mathrm{Ka}$ is sensation, Philemon is intuition, he is too supra-human (he is Zarathustra), extravagantly superior in what he says, and cold. (C.G.J. has not printed the questions he addressed to Philemon nor his answer).

The Man is the inferior function, which is a priest. The colours are barbarous, and represent the four functions again. The snake and bird are feeling and thinking (as the hands of man), the figures intuition and sensation. The repressed things are inferior, even detestable, and they are the bigger in the unconscious. When you get in touch with the unconscious they are like great gods.

You call 'stupidity' a great weakness in man, all the same you put yourself on the actual standpoint of stupidity. Stupidity is a gigantic power, but you must keep away from it. But in allowing it you assume a gigantic power. It makes you formidable, inhuman and powerful. Through not understanding, you force people to super-human efforts to formulate for themselves. Our weaknesses thus used are tremendous forces in the world. We can lay aside our strength but not our weakness, because it is the more powerful. So that is why Ka and Philemon are bigger than the Man, they are supra-human. (Disintegrated into them one is in the collective unconscious).

It is the same motif as the 'Swinging Censer'. ${ }^{2}$ In the night it fills the heavens as a flaming ball. The least unearthly, uninteresting or dead thing is the most powerful in the night (the unconscious). In that dream the audience are all antique people - dead folk, cave dwellers. sermon ad mortuos. It is a divine service for the 'dead'. In the picture there is no

${ }^{2}$ This refers to the dream 'The Night of the Flaming Censer' in John Hubbard, Authentic Dreams of Peter Blobbs (1916); these had been the subject of Jung's seminar at Sennen Cove, Cornwall, in the summer of 1920; see Jung (2014:216-217, 223 n. 9). 
swinging censer-here it is expressed in words; invocations, adorations of god, maybe speechless. But here is a word (sermo) or prayer. You can invoke or adore god in many forms, in religious gestures. The public are the 'dead'. Divine service can be vis à vis to the things in ourselves. This is ancestor worship - and worships that have proved an enormously strong motive in religion in past centuries. The ancestral things - the dead - need to be taken greatest care of lest we begin to suffer from ghost dreams, and we become incarcerated by the spirit of the dead (the collective unconscious).

C.G. J. gave a new face to the old beliefs through turning[?] to analysis of the images of the unconscious. This gift is the transcendent function.

If the person who paints such a picture is irrational the figures would be natural. The two human figures would be close to the man, and the bird and snake enormous.

Zarathustra's two animals are eagle and snake, definitely intellect and feeling. The enormous powers would be the rational processes or powers. Nietzsche returned to the heights -6000 feet up to write Zarathustra. Philemon is the inverse of Christ. Ka is the brother of the devil, is the Antichrist — the Red Pope. Lenin. 